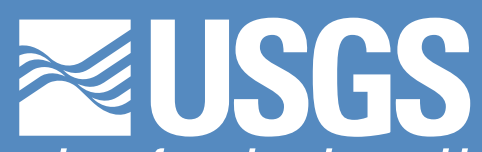

science for a changing world

Water Availability and Use Science Program

Prepared in cooperation with the Utah Department of Natural Resources

\title{
Development of a Method to Identify Complex Wells and Assess the Accuracy of Basin Withdrawals in Utah
}

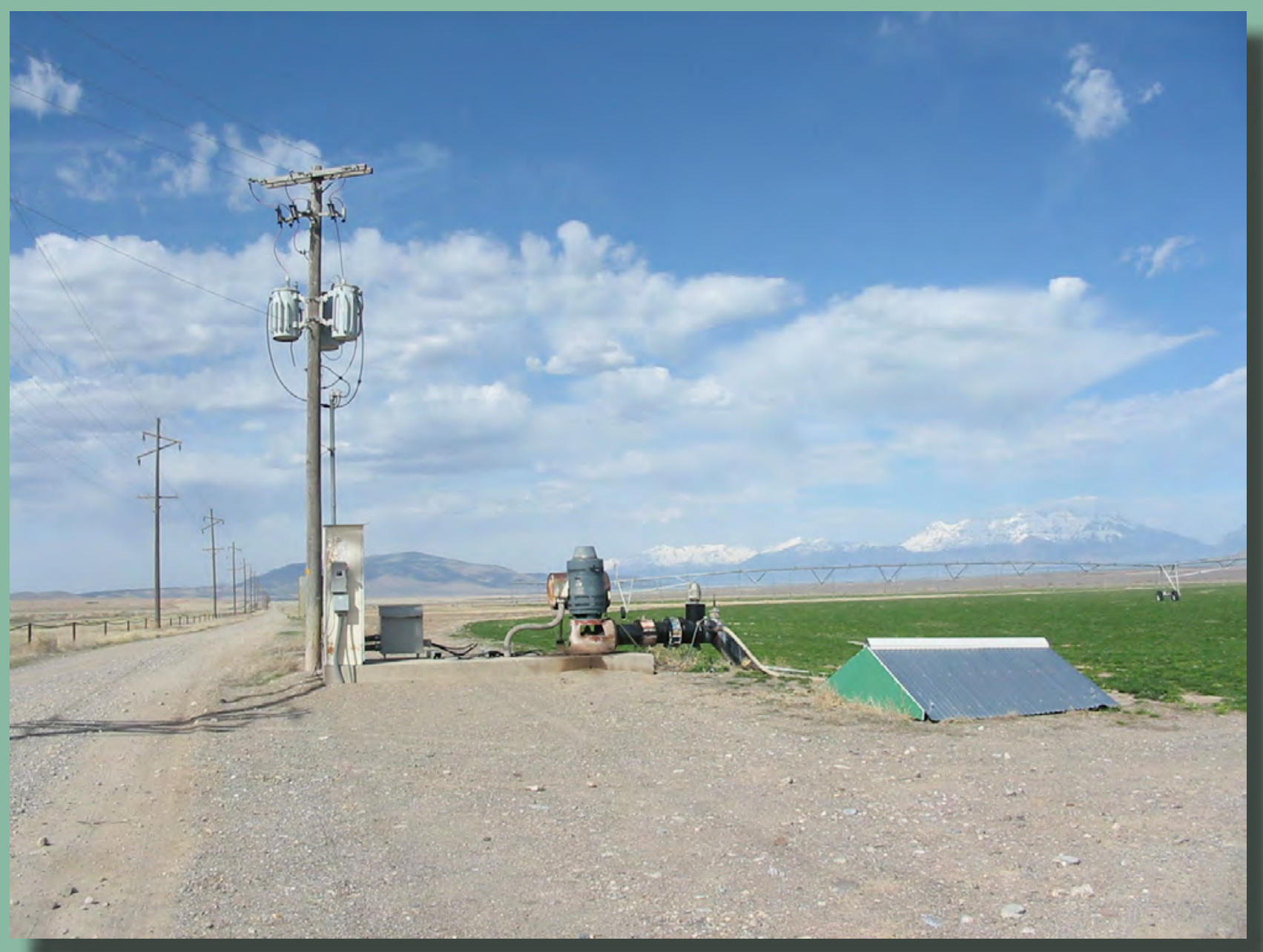

Open-File Report 2020-1106 
Cover Photo: Photograph of Goshen Valley looking north-northeast toward Mount Timpanogos. Photograph by Christopher Wilkowske, U.S. Geological Survey, March 22, 2004. 


\section{Development of a Method to Identify Complex Wells and Assess the Accuracy of Basin Withdrawals in Utah}

By Brittany L. Gold, Cory E. Angeroth, and Thomas M. Marston

Water Availability and Use Science Program

Prepared in cooperation with the Utah Department of Natural Resources

Open-File Report 2020-1106 


\title{
U.S. Department of the Interior \\ DAVID BERNHARDT, Secretary
}

\author{
U.S. Geological Survey \\ James F. Reilly II, Director
}

U.S. Geological Survey, Reston, Virginia: 2020

For more information on the USGS - the Federal source for science about the Earth, its natural and living resources, natural hazards, and the environment—visit https://www.usgs.gov or call 1-888-ASK-USGS.

For an overview of USGS information products, including maps, imagery, and publications, visit https://store.usgs.gov/.

Any use of trade, firm, or product names is for descriptive purposes only and does not imply endorsement by the U.S. Government.

Although this information product, for the most part, is in the public domain, it also may contain copyrighted materials as noted in the text. Permission to reproduce copyrighted items must be secured from the copyright owner.

Suggested citation:

Gold, B.L., Angeroth, C.E., and Marston, T.M., 2020, Development of a method to identify complex wells and assess the accuracy of basin withdrawals in Utah: U.S. Geological Survey Open-File Report 2020-1106, 23 p., https://doi.org/10.3133/ofr20201106.

Associated data for this publication:

Gold, B.L., 2020, Historical power consumption coefficients and 2016 power usage for irrigation wells in Tooele, Parowan, and Goshen Valley, Utah: U.S. Geological Survey data release, https://doi.org/10.5066/P92UVVV6.

ISSN 2331-1258 (online) 


\section{Acknowledgments}

The authors would like to thank James Greer of the Utah Department of Natural Resources, Division of Water Rights for his cooperation and partnership during all phases of the study.

The authors also thank the technicians of the Utah Water Science Center who, over the last

50 years, spent countless hours measuring and recording power consumption coefficients across the state. Without their hard work and dedication, this analysis would not have been possible. 



\section{Contents}

Acknowledgments ……...................................................................................................................

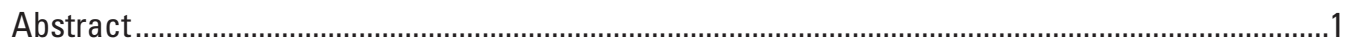

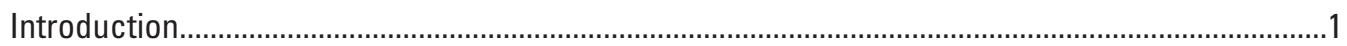

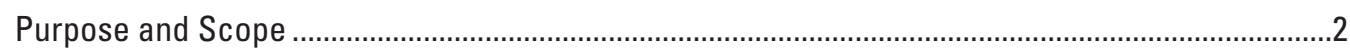

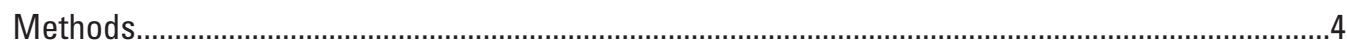

Power Consumption Coefficient and Groundwater Withdrawal .............................................

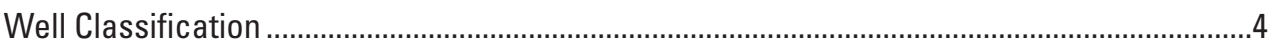

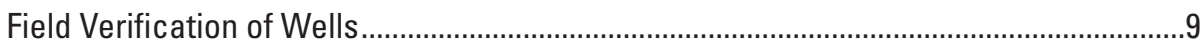

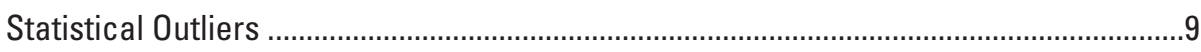

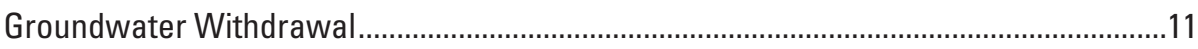

Findings

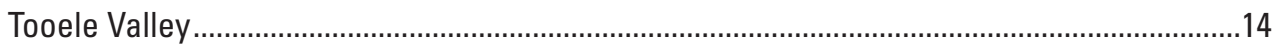

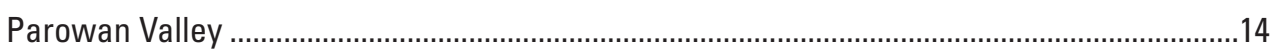

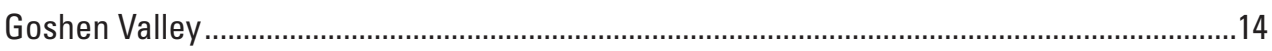

Calculated Versus Directly Measured Withdrawal in Goshen Valley......................................16

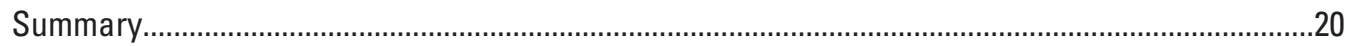

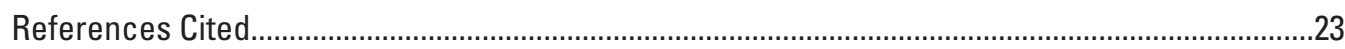

\section{Figures}

1. Map showing location of Tooele, Parowan, and Goshen groundwater

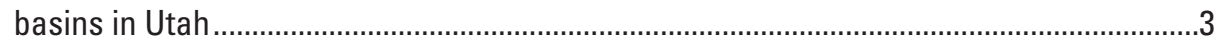

2. Map showing active irrigation wells in Tooele Valley, Utah..............................................

3. Map showing active irrigation wells in Parowan Valley, Utah ............................................6

4. Map showing active irrigation wells in Goshen Valley, Utah..............................................7

5. Graphs showing historical power consumption coefficients for two active irrigation wells in Tooele Valley, Utah ..............................................................................

6. Graphs showing historical power consumption coefficients for two wells in Tooele Valley, Utah

7. Graph showing comparison of season-long power consumption coefficient (PCC) calculated from dedicated flowmeters and the instantaneous measured PCC from the most recently measured PCCs in Goshen Valley, Utah, using 20 wells with dedicated flowmeters, 2016 power consumption, and historical PCCs .........19

8. Graph showing percent difference between dedicated flowmeter withdrawal and withdrawal calculated using other methods in Goshen Valley, Utah, 2016

9. Graphs showing estimated annual groundwater withdrawal calculated using historical minimum power consumption coefficients (PCCs), historical maximum PCCs, historical mean PCCs, valley average PCCs, and the most recently measured PCCs and normalized percent difference between annual groundwater withdrawal calculated using historical mean PCCs and annual groundwater withdrawal calculated using other methods in 2016 for Tooele, Parowan, and Goshen Valleys, Utah

10. Graphs showing wells classified as simple, complex, and borderline in each basin, Tooele, Parowan, and Goshen, Utah, 2016. 


\section{Tables}

1. Coefficient of variation thresholds for classification of irrigation wells based on historical PCCs .8

2. Irrigation well classification by basin in Utah, 2016

3. Irrigation wells with minor statistical outliers in each test basin: Tooele, Parowan, and Goshen, Utah, and the number of wells that changed classification upon removal of outlier power consumption coefficient(s), 2016

4. Historical power consumption coefficient measurements for two wells in Tooele Valley, Utah, 2016

5. Annual groundwater withdrawal from active irrigation wells in Tooele, Parowan, and Goshen Valleys, Utah calculated with and without power consumption coefficient outliers, 2016

6. Calculated groundwater withdrawal using the most recent power consumption coefficients, historical minimum PCCs, and historical maximum PCCs, in Tooele and Parowan Valleys, Utah, 2016.

7. Method definitions for calculating annual groundwater withdrawal and calculated groundwater withdrawal in Utah, 2016.

8. Percent difference between estimated annual groundwater withdrawal calculated using various combinations of historical power consumption coefficients from irrigation wells in Tooele Valley, Utah, 2016.

9. Percent difference between estimated annual groundwater withdrawal calculated using various combinations of historical power consumption coefficients from irrigation wells in Parowan Valley, Utah, 2016

10. Percent difference between estimated annual groundwater withdrawal calculated using various combinations of historical power consumption coefficients from irrigation wells in Goshen Valley, Utah, 2016.

11. Percent difference between estimated annual groundwater withdrawal calculated using various combinations of historical power consumption coefficients from irrigation wells that have historical power consumption coefficients in Goshen Valley, Utah, 2016

12. Percent difference between estimated annual groundwater withdrawal calculated using various combinations of historical power consumption coefficients from irrigation wells that have historical power consumption coefficients, 2016 power usage, and dedicated flowmeters in Goshen Valley, Utah, 2016.

13. Percent difference between estimated annual groundwater withdrawal calculated using various combinations of historical power consumption coefficients from complex irrigation wells that have historical power consumption coefficients, 2016 power usage, and dedicated flowmeters in Goshen Valley, Utah, 2016.

14. Percent difference between estimated annual groundwater withdrawal calculated using various combinations of historical power consumption coefficients from simple irrigation wells that have historical power consumption coefficients, 2016 power usage, and dedicated flowmeters in Goshen Valley, Utah, 2016 
15. Percent difference between estimated annual groundwater withdrawal calculated using various combinations of historical power consumption coefficients from borderline irrigation wells and wells with three or fewer historical power consumption coefficients that have historical power consumption coefficients, 2016 power usage, and dedicated flowmeters in Goshen Valley, Utah, 2016

\section{Conversion Factors}

U.S. customary units to International System of Units

\begin{tabular}{lcl}
\hline \multicolumn{1}{c}{ Multiply } & By & \multicolumn{1}{c}{ To obtain } \\
\hline \multicolumn{3}{c}{ Volume } \\
\hline acre-foot (acre-ft) & 1,233 & cubic meter $\left(\mathrm{m}^{3}\right)$ \\
acre-foot (acre-ft) & 0.001233 & cubic hectometer $\left(\mathrm{hm}^{3}\right)$ \\
\hline \multicolumn{3}{c}{ Flow rate } \\
\hline acre-foot per day (acre-ft/d) & 0.01427 & cubic meter per second $\left(\mathrm{m}^{3} / \mathrm{s}\right)$ \\
acre-foot per year (acre-ft/yr) & 1,233 & cubic meter per year $\left(\mathrm{m}^{3} / \mathrm{yr}\right)$ \\
acre-foot per year (acre-ft/yr) & 0.001233 & cubic hectometer per year $(\mathrm{hm} 3 / \mathrm{yr})$ \\
\hline
\end{tabular}

\section{Abbreviations}

CV coefficient of variation

DWRi Division of Water Rights

GW groundwater

PCC power consumption coefficient

TFM totalizing flowmeter

USGS U.S. Geological Survey 



\title{
Development of a Method to Identify Complex Wells and Assess the Accuracy of Basin Withdrawals in Utah
}

\author{
By Brittany L. Gold, Cory E. Angeroth, and Thomas M. Marston
}

\section{Abstract}

Power consumption coefficients (PCCs) and dedicated flowmeter records for irrigation wells in three Utah groundwater basins were analyzed to develop a method to better characterize the accuracy of annual groundwater withdrawal estimates. The PCC method has been used by the U.S. Geological Survey in Utah since 1963 as a way to estimate groundwater withdrawal. As a result, most irrigation wells in Utah have historic records consisting of multiple PCCs. Over time, numerous wells have been retrofitted with dedicated flowmeters to more accurately describe groundwater use for irrigation. The combination of historical PCCs and flowmeter data was examined to classify wells as simple, complex, or borderline. The PCCs for each well were statistically analyzed for each period of record to determine the PCC coefficient of variation (CV). Variance, standard deviation, and CV also were calculated for each well, yielding similar results. The $\mathrm{CV}$ was selected as the best statistical method for classifying wells. Through field verification and examination of records, CV thresholds were established, allowing wells to be classified as simple, complex, or borderline. This well classification provides information on the uncertainty and best methods for quantifying annual groundwater withdrawals from irrigation wells in a basin.

Annual irrigation groundwater withdrawals in Tooele, Parowan, and Goshen Valleys were calculated by using various combinations of historical PCC records and data from dedicated flowmeters. Differences between annual groundwater withdrawal using the most recent measurements, and historic minimum, maximum, mean, and median PCCs were compared. The smallest percent difference between annual groundwater withdrawal calculated using the most recently measured PCCs, which is the current method for calculating withdrawal in most basins, in Tooele and Parowan Valleys, was 7 and 9 percent respectively, using historical median and mean.

In Goshen Valley, most wells have dedicated flowmeters, and there is a subset of wells that have 2016 power usage data, historical PCC records, and 2016 reported dedicated flowmeter withdrawal. Using this subset of irrigation wells, the smallest percent different between withdrawal from dedicated flowmeters and withdrawal calculated by using other methods was 5 percent (using withdrawal calculated with historical mean PCCs for each well). Annual groundwater withdrawal calculated using the most recently measured PCCs was 9-percent less than dedicated flowmeter reported withdrawal. So, if withdrawal from dedicated flowmeters is as close to reality as possible, then in the case of Goshen Valley, using historical mean PCCs to calculate withdrawal is closer to reality than using the most recently measured PCCs to calculate withdrawal.

\section{Introduction}

Accurate determination of water use, particularly groundwater use, is a critical component of assessing water availability in the arid western United States. A large component of total water use is groundwater withdrawal for irrigation. Since 1963, the U.S. Geological Survey (USGS) Utah Water Science Center, in cooperation with the Utah Department of Natural Resources Division of Water Rights (DWRi), has estimated annual groundwater withdrawal from basins in Utah.

Over time, irrigation systems have changed from surface water ditch diversions to simple groundwater-based sprinkler systems to wheel lines and center pivot sprinklers to more complex integrated systems with multiple wells and variable speed pumps that supply one or more systems. A "complex system" is defined by the Colorado District Court, Water Division No. 2 as "any system where the total dynamic head at the pump will vary due to multiple discharge locations in a pipeline, or where the method of delivery will vary between open discharge, gated pipe, or sprinkler system during a single irrigation season, or where multiple wells discharge into a common pipeline" (Colorado Department of Natural Resources Division of Water Resources, unpub. data, 2008). 
One aspect needed to better quantify annual groundwater withdrawals is understanding the role of complex well systems. Understanding the role of complex well systems includes a thorough assessment of the number of complex well systems, information about wells that have changed from simple to complex configurations, and an evaluation of the effect the overall accuracy of discrete measurements taken from complex well systems has on estimates of groundwater withdrawal. The effects of well configuration, conversion from simple to complex wells, and the presence or absence of dedicated flowmeters on withdrawal estimates made in the Tooele, Parowan, and Goshen groundwater basins are assessed in this report (fig. 1). Withdrawal estimates for these basins were made by evaluating power consumption records for individual wells. The assessment will allow the DWRi to consider options for improving irrigation withdrawal estimates in the future.

The power consumption coefficient (PCC) method has been used by the USGS in Utah since 1963 as a way to estimate groundwater withdrawal. The power consumption coefficient is determined by measuring the amount of electrical energy required to pump a known volume of water. Following the irrigation season, the total amount of electricity used by the pump is multiplied by the PCC to estimate the volume of water withdrawn that season from a given well. Annual groundwater withdrawal from most irrigation basins in Utah is currently calculated using the most recently measured PCC record for each well, except in Parowan and Goshen Valleys. In Parowan Valley, the average of each well's most recently measured PCC is used to develop a valley average, which is then applied to all wells. In Goshen Valley, flowmeters are permanently installed on some wells, and a combination of measured withdrawals from permanent flowmeters and calculated withdrawals using the most recently measured PCC are used. For the purpose of this report, permanently installed flowmeters are referred to as dedicated flowmeters. Historically, wells were revisited every $1-3$ years to update the PCC. The PCCs were last measured in Tooele Valley in 2017; Parowan Valley in 2013; and Goshen Valley in 2014. The frequency of visits helped to improve accuracy because the PCC can change over time for a variety of reasons, such as change in depth to water, change in irrigation practice, pump wear, or system configuration.

Large variability in the PCC for individual wells could indicate that the well is part of a complex irrigation system and can be used as a screening tool to identify complex wells. Complex wells increase the uncertainty of groundwater withdrawal estimates. Uncertainty regarding basin-wide withdrawal estimates is likely to increase with the growing numbers of complex wells.

\section{Purpose and Scope}

The purpose of this study is to assess the effectiveness and accuracy of annual groundwater withdrawal estimates in Utah and the impact of dedicated flowmeters and complex wells on withdrawal estimates. Specifically, this study assesses the percent difference among annual groundwater withdrawal from irrigation wells calculated using different combinations of PCCs. The study also tests a statistical screening method by using existing PCCs to identify simple and complex wells and the effects of complex wells in three test basins.

The classification of wells as simple or complex is based on variability in historical PCCs and compose the first part of this study. The second part of this study evaluates the effects of complex wells on basin-wide estimates of annual withdrawal.

After complex wells have been identified, the annual withdrawal estimates for each well are recalculated using the historical maximum and minimum PCCs. The basin-wide annual withdrawal calculated by using historical maximum and minimum PCCs represents the range of estimated groundwater withdrawal and can be used to bracket and assess the impacts of complex wells on the annual basin-wide withdrawal estimates. Specific components of this analysis include computing the annual estimated withdrawal for the three basins based on historical PCCs using the (1) most recently measured PCC for all wells, (2) minimum PCC for all wells, (3) maximum PCC for all wells, (4) mean PCC for all wells, (5) median PCC for all wells, (6) maximum PCC for complex wells and most recently measured PCC for simple and borderline wells, (7) maximum PCC for complex and borderline wells and most recently measured PCC for simple wells, (8) minimum PCC for complex wells and most recently measured PCC for simple and borderline wells, (9) minimum PCC for complex and borderline wells and most recently measured PCCs for simple wells, and (10) valley average PCCs. Additional elements in this analysis include assessing the percent difference between the measured PCC estimated annual withdrawal and the estimated annual withdrawal using various combinations of PCCs to calculate withdrawal. This analysis also includes assessing sources of variability of PCCs and estimated withdrawals to evaluate the accuracy of historic estimates and establish a method for improved data collection. 


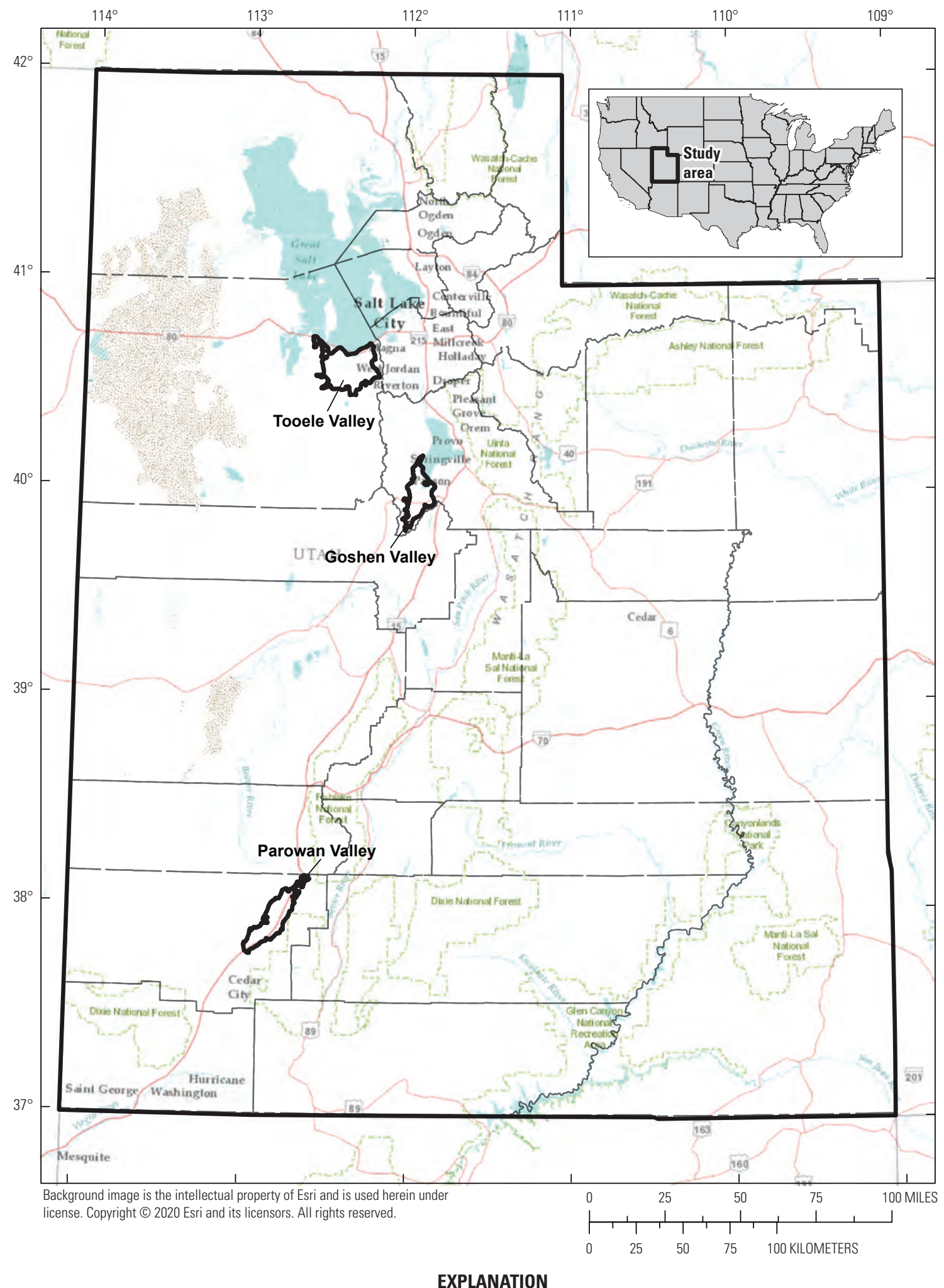

EXPLANATION

Study groundwater basins

County boundaries

Figure 1. Location of Tooele, Parowan, and Goshen groundwater basins in Utah. 


\section{Methods}

Groundwater withdrawal estimates in Utah have largely been computed using PCCs. Statistical analyses of the changes in a well's PCC can be used to classify wells as simple, complex, or borderline. Historical PCC records also are used to better understand estimation errors and best methods for determining agricultural water use.

\section{Power Consumption Coefficient and Groundwater Withdrawal}

The PCC is determined by measuring the amount of electrical power used to pump a volumetric rate of water (gallons per minute) from the ground to the crop. Annual groundwater withdrawal can then be estimated by multiplying the PCC by the annual electric energy usage of the well. The PCC method for estimating groundwater withdrawal has been directly compared (Dash and others, 1999) to groundwater withdrawal measured with totalizing flowmeters (TFM). Values of groundwater withdrawal from direct measurements with TFM and estimates from PCC compare favorably except when a well is part of a complex system. When a well is part of a complex system, the two methods typically yield different results.

Estimates of groundwater withdrawal from irrigation wells in Utah are computed using the PCC method (Hurr and Litke, 1989), which has changed little during the last 50 years. The PCC method requires a site visit to the well to determine the amount of electric power (kilowatts) required to pump a volumetric rate of water out of the ground and transport it to the crop. Electric power meters, at the wellhead, measure the electric power that passes through the meter by the revolution of a dial on an analog meter or digital bar on a digital meter. The quantity of electric power is calculated from the following equation:

$$
a=r * 3.6 * k
$$

where

$$
\begin{gathered}
\text { as the electric power demand, in kilowatts; } \\
r \\
\text { is the measured average time of meter cycle, } \\
\text { in cycles per second; } \\
\text { is a conversion factor in kilowatt-seconds per } \\
\text { watt-hour; and } \\
k \text { is watt-hours per cycle (imprinted on the front } \\
\text { of power meter). }
\end{gathered}
$$

Once electric power is quantified, the resulting discharge rate (volume per time) of water pumped by the electric power is determined. Discharge rate is measured by using a temporary flowmeter fitted to the well plumbing during a field visit (Marston, 2017). Flowmeters measure water velocity (length per time), which is multiplied by the cross-sectional area of the pipe to determine the groundwater discharge rate (volume per time). Electric power (kilowatts) and discharge are converted to a PCC using the equation:

$$
P C C=(w * 0.1841) / a
$$

where

$$
\begin{gathered}
\text { PCC } \quad \text { is the measured power consumption } \\
\text { coefficient, in acre-feet per } \\
1,000 \text { kilowatt-hours; } \\
w \quad \text { is instantaneous groundwater discharge, in } \\
\text { gallons per minute; } \\
a \quad \text { is the electric power demand, in } \\
\text { kilowatts; and } \\
0.1841 \quad \text { is a conversion factor, (1 acre-feet * } \\
60 \text { minute *1,000) per ( } 325,851 \text { gallons * } \\
1 \text { hour * } 1,000 \text { kilowatts). }
\end{gathered}
$$

\section{Well Classification}

Method development and testing was done on wells in the following groundwater basins: Tooele, Parowan, and Goshen Valleys (figs. 2, 3, and 4). For each basin, data from field books that contained PCC computations in paper form were converted to an electronic format, which allowed for data analysis and organization. The PCC's for Tooele, Parowan, and Goshen Valleys are available in a USGS data release (Gold, 2020). The PCC's were only established for wells operating during the site visit. The PCCs for each well were statistically analyzed for each period of record to determine the PCC coefficient of variation (CV) and evaluate statistical outliers in the dataset for each well. Variance, standard deviation, and $\mathrm{CV}$ were calculated for each well and yielded similar results. The CV was selected as the best statistical method for classifying wells as simple or complex because of its ability to compare datasets to each other regardless of the magnitude of values in each dataset (Reed and others, 2002).

Field verification of select wells with variability in historical PCC records was done for wells in Tooele Valley. Field verification consisted of inspecting the wells for multiple pipes, controls, and pivots that would indicate a complex well configuration. Wells were visited to verify they had been correctly classified using CV.

For wells with more than three historical PCC records, statistical outliers were calculated for each well's PCC using the interquartile range to evaluate the effect of outliers on basin-wide groundwater withdrawal (Zwillinger and Kokoska, 2000). The CV for each of these wells was then reevaluated after removing statistical outliers from the dataset. 


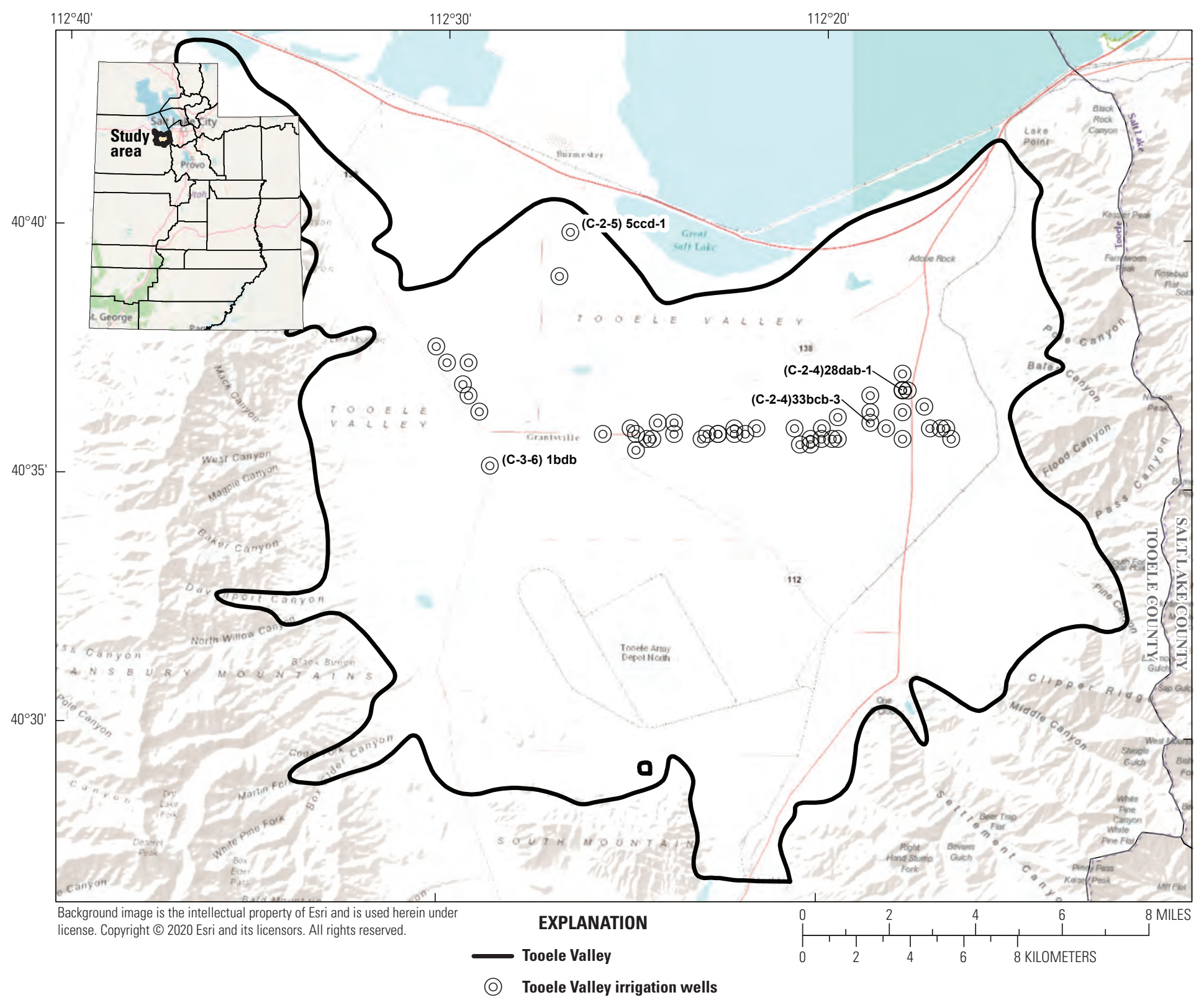

Figure 2. Active irrigation wells in Tooele Valley, Utah. 


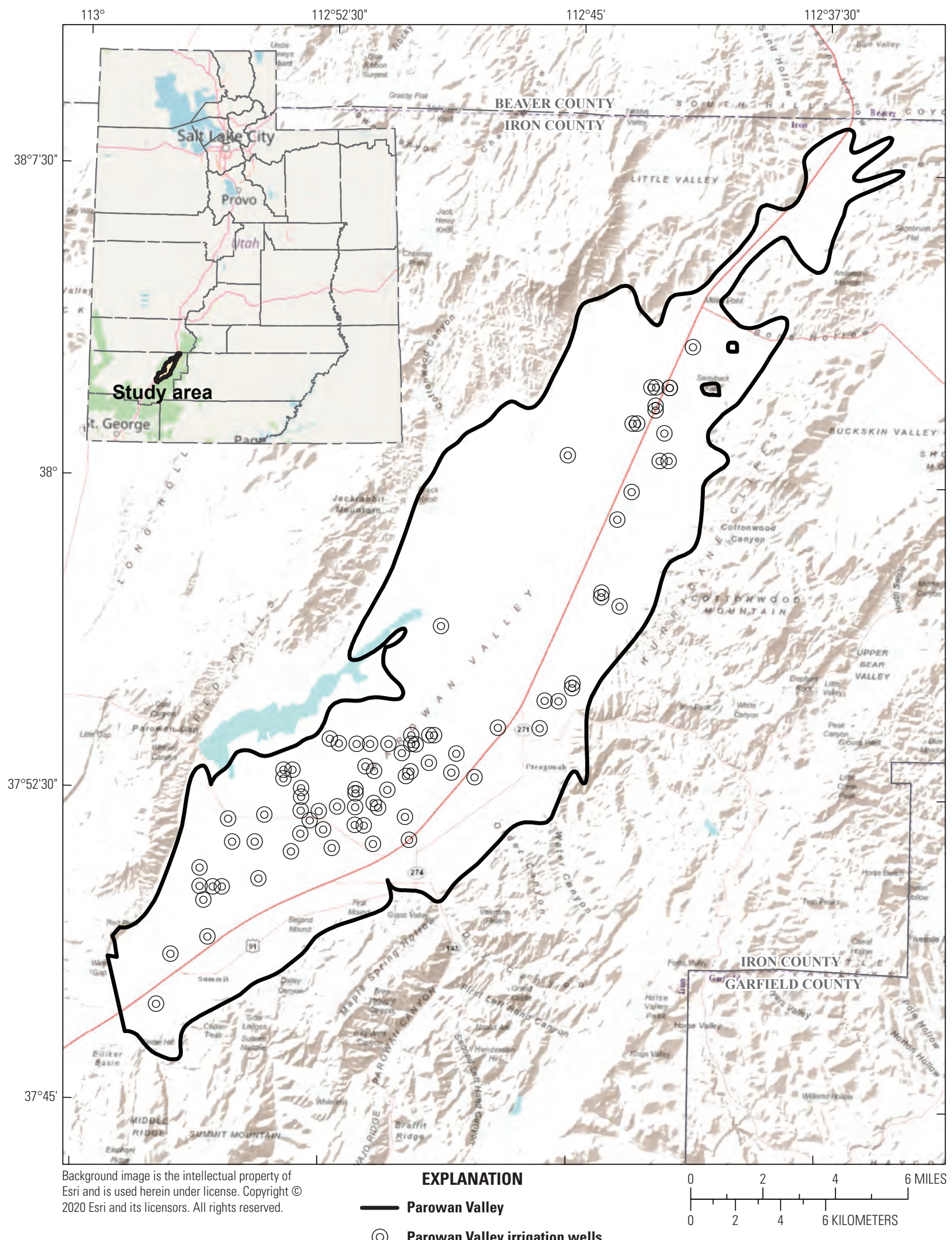

Figure 3. Active irrigation wells in Parowan Valley, Utah. 


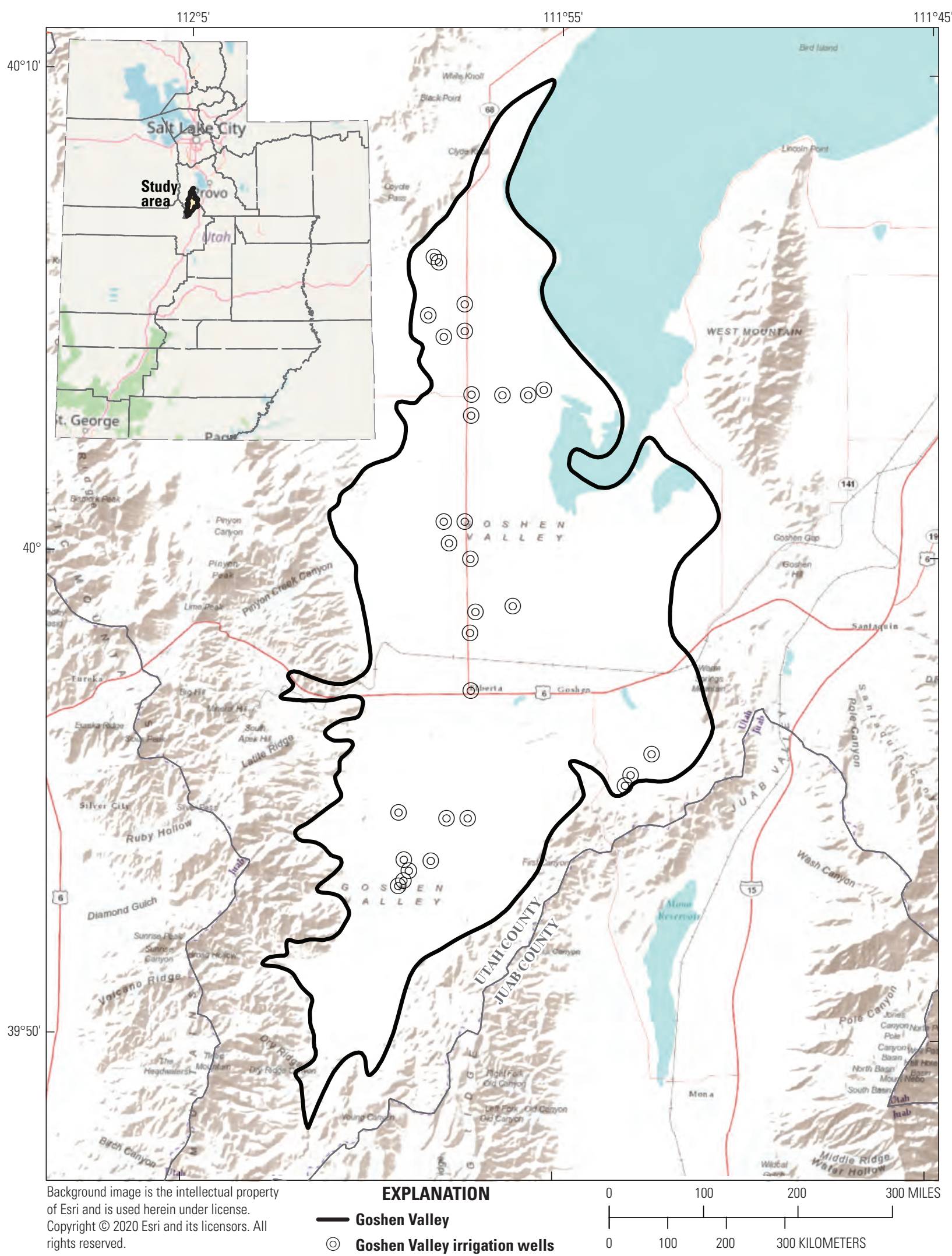

Figure 4. Active irrigation wells in Goshen Valley, Utah. 
Through field verification and examination of records, the following thresholds were established. If the $\mathrm{CV}$ for a well is less than 0.2 , the well is classified as simple. If the $\mathrm{CV}$ is greater than 0.25 , the well is classified as complex. A third group consisting of borderline wells also was established. If the CV for a well is between these two values or the well has three or fewer historical PCCs, the well is classified as borderline (table 1). Historical PCC records for two wells in Tooele Valley indicated that the range of PCC values for well (C-2-4)28dab-1 (classified as complex) was greater than the range for well (C-3-6) $1 \mathrm{bdb}$ (classified as simple) and the $\mathrm{CV}$ was higher for the complex well than for the simple well (fig. 5).

In each test basin, active irrigation wells (as of 2016) were classified based on the CV of their historical PCCs. In Tooele Valley, there were 46 active irrigation wells (none of which had dedicated flowmeters): 23 wells were classified as complex, 7 wells were classified as simple, 1 well was classified as borderline, and 15 wells had 3 or fewer historical records and were not classified. In Parowan Valley, there were 115 active irrigation wells (none of which had dedicated flowmeters): 5 wells were classified as complex, 47 wells were classified as simple, 7 wells were classified as borderline, and 17 wells had 3 or fewer historical records and were not classified. There were 39 active irrigation wells in Parowan
Table 1. Coefficient of variation thresholds for classification of irrigation wells based on historical power consumption coefficients (PCCs) .

$[<$, less than; $>$, greater than, $\leq$, less than or equal to $]$

\begin{tabular}{ccc}
\hline Classification & \\
\hline Simple & Complex & $\begin{array}{c}\text { Borderline or } \leq \text { three } \\
\text { historical PCCs }\end{array}$ \\
\hline$<0.2$ & $>0.25$ & $0.20-0.25$ \\
\hline
\end{tabular}

Valley that did not have historical PCC records. These wells have historically been assigned the Parowan Valley valley average PCC from the most recent PCC ratings. In Goshen Valley, there were 30 active irrigation wells, of which 24 had dedicated flowmeters; 8 wells were classified as complex, 4 wells were classified as simple, 5 wells were classified as borderline, and 13 wells had 3 or fewer historical PCC records and were not classified. Twenty of the active irrigation wells in Goshen Valley have dedicated flowmeters, 2016 power-usage data, and historical PCCs; four wells have dedicated flowmeters, but the 2016 power use data was not reported; six wells do not have dedicated flowmeters; these six wells only have 2016 power use and historical PCCs (table 2).

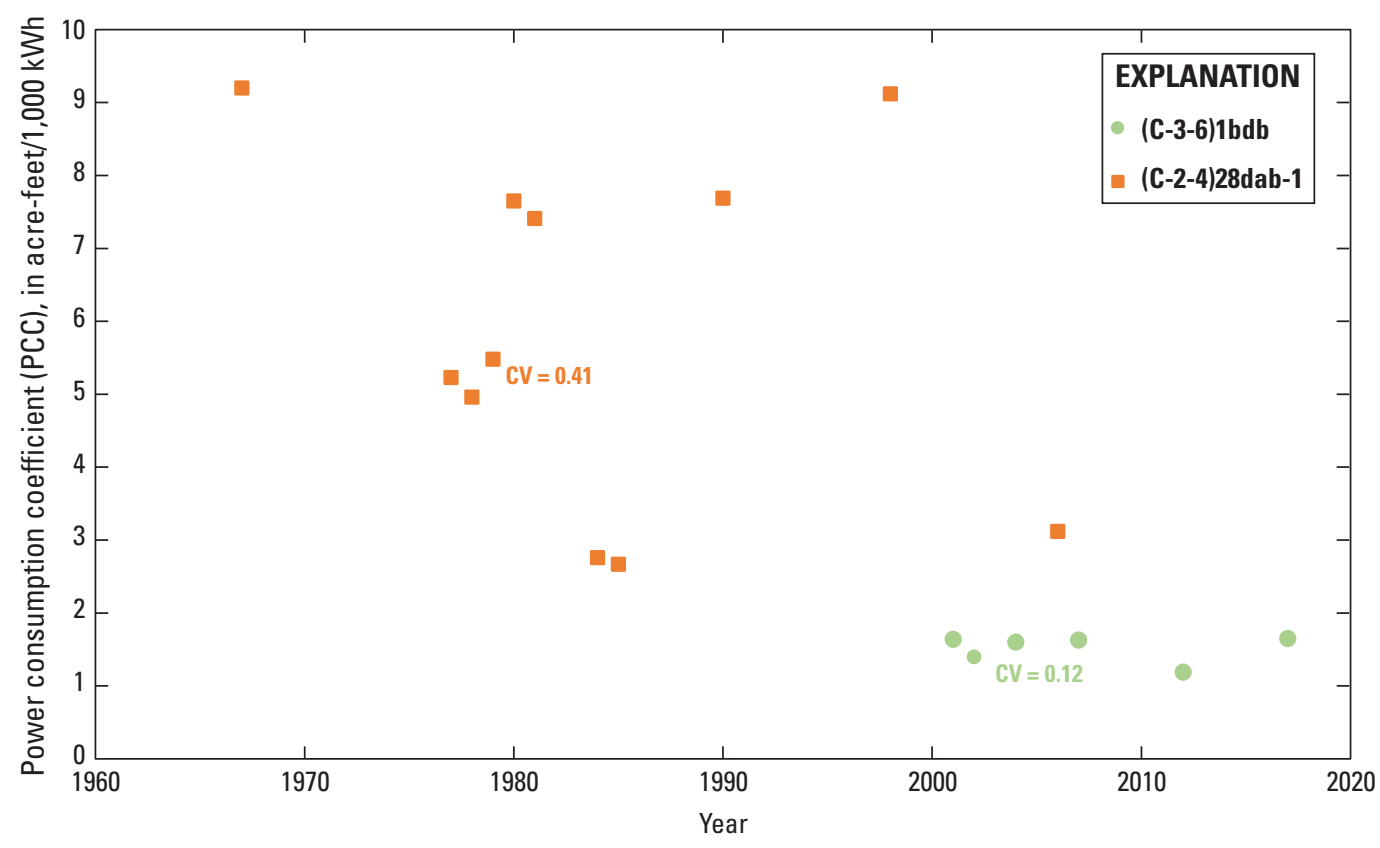

Figure 5. Historical power consumption coefficients (PCCs) for two active irrigation wells in Tooele Valley, Utah. 
Table 2. Irrigation well classification by basin in Utah, 2016.

$[\leq$, less than or equal to; PCC, Power consumption coefficient; - , no data $]$

\begin{tabular}{|c|c|c|c|c|c|c|c|}
\hline $\begin{array}{l}\text { Active } \\
\text { irrigation } \\
\text { wells }\end{array}$ & Meter type & $\begin{array}{l}\text { Wells with } \\
\text { dedicated } \\
\text { flowmeters }\end{array}$ & $\begin{array}{c}\text { Complex } \\
\text { wells }\end{array}$ & $\begin{array}{c}\text { Simple } \\
\text { wells }\end{array}$ & $\begin{array}{l}\text { Borderline } \\
\text { wells }\end{array}$ & $\begin{array}{c}\leq \text { Three } \\
\text { historical } \\
\text { measurements }\end{array}$ & $\begin{array}{l}\text { Wells without } \\
\text { PCC records }\end{array}$ \\
\hline \multicolumn{8}{|c|}{ Tooele Valley, Utah } \\
\hline \multirow{2}{*}{46} & Dedicated flowmeter & 0 & - & - & - & - & - \\
\hline & No dedicated flowmeter & 46 & 23 & 7 & 1 & 15 & 0 \\
\hline \multicolumn{8}{|c|}{ Parowan Valley, Utah } \\
\hline \multirow{2}{*}{115} & Dedicated flowmeter & 0 & - & - & - & - & - \\
\hline & No dedicated flowmeter & 115 & 5 & 47 & 7 & 17 & 39 \\
\hline \multicolumn{8}{|c|}{ Goshen Valley, Utah } \\
\hline \multirow{2}{*}{30} & Dedicated flowmeter & 24 & 8 & 4 & 4 & 8 & 0 \\
\hline & No dedicated flowmeter & 6 & 一 & - & 1 & 5 & 0 \\
\hline
\end{tabular}

\section{Field Verification of Wells}

Field verification of wells in Tooele Valley was done in June 2018 for 14 of the 46 active wells. Eleven wells were field verified as complex. Six of these wells were classified as complex based on $\mathrm{CV}$ and two fell within the borderline range. Three of the field verified complex wells had less than four historical PCCs and were not classified on the basis of CV. Two wells were field verified as simple, of which one well was classified as simple by using the $\mathrm{CV}$ method. Field verification supported the thresholds established for classification of wells as simple, complex, and borderline based on the $\mathrm{CV}$ of each well's historical PCCs.

\section{Statistical Outliers}

The interquartile range was used to calculate minor statistical outliers for each well to determine if outliers affected classification, if outliers affected basin-wide annual groundwater withdrawal, and if outliers should be removed from or included in the dataset. To understand the effect of outliers, PCCs outside of the interquartile range for each well were identified as statistical outliers. The CV was reevaluated for each well with a PCC identified as a statistical outlier to understand if removal of outliers changed the well's classification, for example, from complex to simple. Basin-wide annual groundwater withdrawal was calculated with the complete dataset including outliers and separately with outliers removed to determine if outliers influence basin-wide annual groundwater withdrawal. Removal of outliers had the largest impact on classifications of wells in Tooele Valley, which has more complex wells than Parowan or Goshen Valleys. The number of statistical outliers calculated for each test basin and how the removal of the outlier PCC(s) affected classification, is presented in table 3 .

In Tooele Valley, 16 wells had 1 or more historical PCCs flagged as a statistical outlier. Removing outliers from the historical record and recalculating CV changed the classification of eight wells (table 3). With outliers removed, recalculated $\mathrm{CV}$ changed four well classifications from complex to simple; three wells changed classification from complex to borderline or had three or fewer PCCs; one well changed classification from borderline to simple; and eight wells classification did not change. Examples of two wells with PCCs flagged as outliers are presented in table 4 and figure 6. Well (C-2-4)3bcb-3 was classified as complex with all historical records used to calculate $\mathrm{CV}(\mathrm{CV}=0.34)$. This well had three PCC records flagged as statistical outliers: 6.5, 7.03, and 2.01 (fig. 6). Removing those values and recalculating the $\mathrm{CV}$ reclassified this well as simple (table 4; $\mathrm{CV}=0.11)$. Well (C-2-5)5ccd-1 was classified as borderline with all historical PCC records used to calculate CV (table 4; $\mathrm{CV}=0.22$ ). This well had one PCC of 1.47 flagged as a statistical outlier. Removal of this outlier PCC changed the well's classification from borderline to simple (table 4; $\mathrm{CV}=0.10)$. 
Table 3. Irrigation wells with minor statistical outliers in each test basin: Tooele, Parowan, and Goshen, Utah, and the number of wells that changed classification upon removal of outlier power consumption coefficient(s), 2016.

$[\leq$, less than or equal to $]$

\begin{tabular}{lccc}
\hline \multicolumn{1}{c}{ Classification change with outlier(s) removed } & \multicolumn{2}{c}{ Statistical outliers } \\
\cline { 2 - 4 } & $\begin{array}{c}\text { Tooele } \\
\text { Valley }\end{array}$ & $\begin{array}{c}\text { Parowan } \\
\text { Valley }\end{array}$ & $\begin{array}{c}\text { Goshen } \\
\text { Valley }\end{array}$ \\
\hline Classification change from complex to simple & 4 & 0 & 1 \\
Classification change from borderline to simple & 1 & 1 & 1 \\
Classification change from complex to borderline or $\leq$ three historical records & 3 & 1 & 3 \\
Classification change from simple to $\leq$ three historical records & 0 & 1 & 0 \\
Classification did not change & 8 & 19 & 1 \\
\hline Total wells with statistical outlier(s) & 16 & 22 & 6 \\
\hline
\end{tabular}

Table 4. Historical power consumption coefficient measurements for two wells in Tooele Valley, Utah, 2016.

[PCC, power consumption coefficient; acre-ft, acre-foot; $\mathrm{kWh}$, kilowatt-hours; $\mathrm{CV}$, coefficient of variation; - , no data]

\begin{tabular}{|c|c|c|c|c|c|c|c|c|c|c|c|c|c|c|c|c|c|c|}
\hline \multicolumn{19}{|c|}{ PCC in acre-ft/1,000 kWh } \\
\hline Year & 1975 & 1977 & 1978 & 1979 & 1980 & 1981 & 1987 & 1988 & 1990 & 1993 & 1995 & 2000 & 2001 & 2005 & 2007 & 2017 & $\begin{array}{c}\text { CV } \\
\text { including } \\
\text { statistical } \\
\text { outliers }\end{array}$ & $\begin{array}{c}\text { CV } \\
\text { excluding } \\
\text { statistical } \\
\text { outliers }\end{array}$ \\
\hline $\begin{array}{r}1,2(\mathrm{C}-2-4) \\
33 \mathrm{bcb}-3\end{array}$ & 3.27 & 4.03 & 3.64 & 3.72 & 3.8 & 3.7 & - & 4.72 & - & - & 4 & - & 6.5 & - & 7.03 & 2.01 & 0.34 & 0.11 \\
\hline
\end{tabular}

1PCCs considered statistical outliers are highlighted.

${ }^{2}$ With outliers removed and $\mathrm{CV}$ recalculated, the classification of this well changes from complex to simple.

${ }^{3}$ With outliers removed and CV recalculated, the classification of this well changes from borderline to simple.

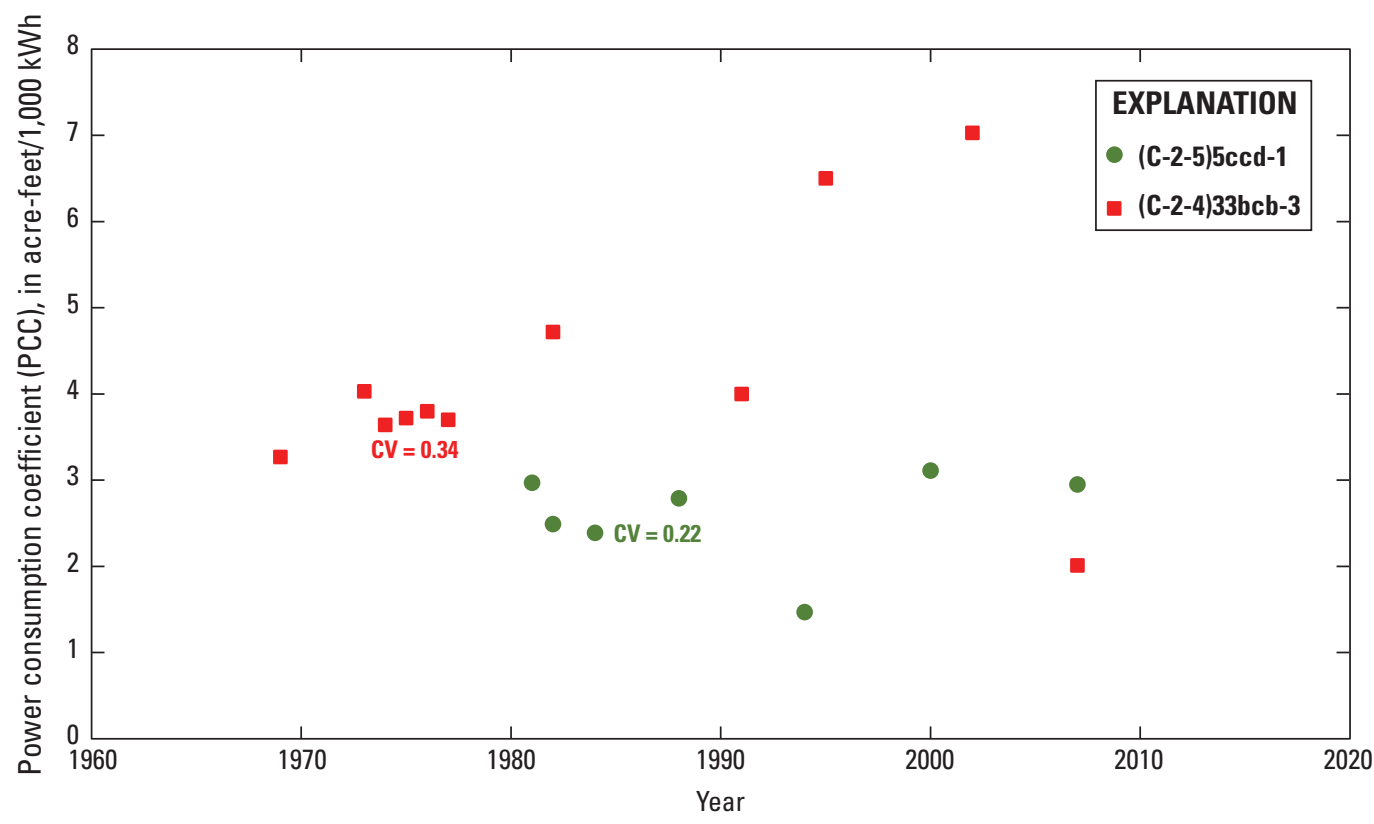

Figure 6. Historical power consumption coefficients (PCCs) for two wells in Tooele Valley, Utah. 
In Parowan Valley, 22 wells had 1 or more historical PCCs flagged as statistical outliers. Removing outliers from the historical record and recalculating $\mathrm{CV}$ changed the classification of three wells (table 3 ). When the outlier(s) was removed, one well's recalculated CV changed the well's classification from borderline to simple, one well changed classification from complex to borderline, and one well was no longer classified because of three or fewer historical records.

In Goshen Valley, six wells had one or more historical PCCs flagged as a statistical outlier. Removing outliers from the historical record and recalculating CV changed the classification of five wells (table 3). When the outlier was removed, one well's classification changed from complex to simple, one well's classification changed from borderline to simple, three wells classifications changed from complex to borderline or three or fewer historical PCCs, and one well's classification did not change.

\section{Groundwater Withdrawal}

All calculations of annual basin-wide groundwater withdrawal were completed with outliers included and excluded from each dataset. These calculations included using each well's most recently measured, historical minimum, historical maximum, historical mean, historical median PCC, and valley average of the most recently measured PCCs to calculate basin-wide annual groundwater withdrawal. There was less than 5-percent difference between annual groundwater withdrawal calculated with and without statistical outliers, except in Tooele Valley where the difference was 19 percent when the maximum historical PCC for each well was used to calculate withdrawal (table 5). Tooele Valley has the most complex well systems, and these complex well systems have the largest range of PCC values of the three test basins. Because of the nature of a complex well system and the lack of overall impact on withdrawal calculated with the exclusion of outliers, the outliers were included in withdrawal calculations.

Table 5. Annual groundwater withdrawal from active irrigation wells in Tooele, Parowan, and Goshen Valleys, Utah, calculated with and without power consumption coefficient (PCC) outliers, 2016.

[GW, groundwater; acre-ft, acre-foot; \%, percent]

\begin{tabular}{|c|c|c|c|c|}
\hline $\begin{array}{l}\text { PCC used to calculate } \\
\text { withdrawal }\end{array}$ & $\begin{array}{c}2016 \text { Annual GW } \\
\text { withdrawal (acre-ft) } \\
\text { calculated with PCCs }\end{array}$ & $\begin{array}{c}2016 \text { Annual GW } \\
\text { withdrawal (acre-ft) } \\
\text { calculated with PCC } \\
\text { outliers removed }\end{array}$ & $\begin{array}{l}\text { Difference between } \\
\text { annual GW withdrawal } \\
\text { (acre-ft) calculated with } \\
\text { and without PCC outliers }\end{array}$ & $\begin{array}{l}\text { Percent difference between } \\
\text { annual GW withdrawal (\%) } \\
\text { calculated with and without } \\
\text { PCC outliers }\end{array}$ \\
\hline \multicolumn{5}{|c|}{ Tooele Valley } \\
\hline Most recent (measured) & 5,394 & 5,449 & -55 & -1 \\
\hline Minimum & 4,074 & 4,215 & -141 & -3 \\
\hline Maximum & 8,587 & 7,190 & 1,397 & 19 \\
\hline Mean & 5,962 & 5,678 & 284 & 5 \\
\hline Median & 5,758 & 5,687 & 71 & 1 \\
\hline Valley average & 5,693 & 5,727 & -34 & 0 \\
\hline \multicolumn{5}{|c|}{ Parowan Valley } \\
\hline Most recent (measured) & 36,642 & 37,111 & -469 & -1 \\
\hline Minimum & 32,997 & 34,348 & $-1,351$ & -4 \\
\hline Maximum & 46,693 & 45,304 & 1,389 & 3 \\
\hline Mean & 39,795 & 39,832 & -37 & 0 \\
\hline Median & 39,937 & 39,942 & -5 & 0 \\
\hline Valley average & 37,079 & 37,503 & -424 & -1 \\
\hline \multicolumn{5}{|c|}{ Goshen Valley } \\
\hline Most recent (measured) & 22,646 & 22,082 & 564 & 3 \\
\hline Minimum & 22,433 & 21,869 & 564 & 3 \\
\hline Maximum & 22,688 & 22,124 & 564 & 3 \\
\hline Mean & 22,575 & 22,011 & 564 & 3 \\
\hline Median & 22,576 & 22,012 & 564 & 3 \\
\hline Valley average & 22,945 & 22,270 & 675 & 3 \\
\hline
\end{tabular}


As noted, CV was selected as the best statistical method for classifying wells as simple or complex because of its ability to compare datasets to each other regardless of the magnitude of values in each dataset (Reed and others, 2002). Field verification supports the classification threshold and the need for the borderline category. Visual inspection of the range of each well's historical PCC records on scatter plots also support the classifications. In some cases, removal of outliers changes well classification; however, to minimize the amount of qualitative bias in the dataset, the outliers were included.

\section{Findings}

Annual groundwater withdrawal for 2016 was calculated for each test basin using a combination of each irrigation well's historical PCCs, which included each irrigation well's most recently measured PCC, historical minimum PCC, historical maximum PCC, historical mean PCC, historical median PCC, and a combination of PCC values based on well classification of simple, complex, or borderline. These different methods were used to calculate annual groundwater withdrawal to evaluate what, if any, impact different irrigation well configurations and different methods for calculating withdrawal have on the calculated basin-wide withdrawal.

Tooele and Parowan Valleys have the most complex and simple irrigation wells of the three test basins, respectively (table 2; figs. 10A, 10B). Eighty percent of active irrigation wells in Goshen Valley have dedicated flowmeters (fig. 10C); this basin will be discussed separately. When the minimum historical PCC for each irrigation well is used to calculate the annual groundwater withdrawal in Tooele Valley, the 2016 annual groundwater withdrawal is 24-percent less than the withdrawal calculated using each irrigation well's most recently measured PCC (table 6). Likewise, if the maximum historical PCC for each irrigation well is used, the 2016 annual groundwater withdrawal is 59-percent greater than the most recently measured PCCs. When the minimum historical PCC for each irrigation well is used to calculate the annual groundwater withdrawal in Parowan Valley, the 2016 withdrawal is 10-percent less than withdrawal calculated using each irrigation well's most recently measured PCC (table 6). Likewise, if maximum historical PCC is used, the 2016 withdrawal is 27-percent greater than the withdrawal calculated using the most recently measured PCCs (table 6). In Tooele Valley, with over 50 percent of its wells classified as complex, estimates of groundwater withdrawal could be overestimated or underestimated by 59 and 24 percent, respectively. In Parowan Valley, with over 40 percent of its wells classified as simple, estimates of groundwater withdrawal could be overestimated or underestimated by 27 and 10 percent, respectively. From this analysis, larger CVs created by more complex wells result in a larger spread between minimum and maximum PCCs. Assuming that minimum-maximum is a measure of error, in basins with larger numbers of complex wells, the error associated with groundwater withdrawals is larger.

Table 6. Calculated groundwater withdrawal using the most recent power consumption coefficients (PCCs), historical minimum PCCs, and historical maximum PCCs in Tooele and Parowan Valleys, Utah, 2016.

[GW, groundwater; acre-ft, acre-foot; \%, percent; -, no data]

\begin{tabular}{lccc}
\hline $\begin{array}{c}\text { PCC used to calculate } \\
\text { withdrawal }\end{array}$ & $\begin{array}{c}\text { 2016 Annual } \\
\text { GW withdrawal } \\
\text { (acre-ft) }\end{array}$ & $\begin{array}{c}\text { Difference in annual GW withdrawal } \\
\text { (acre-ft) from withdrawal calculated } \\
\text { with most recently measured PCC1 }\end{array}$ & $\begin{array}{c}\text { Percent difference in annual GW } \\
\text { withdrawal (\%) from withdrawal calculated } \\
\text { with most recently measured PCC2 }\end{array}$ \\
\hline Most recent (measured) & 5,394 & Tooele Valley & - \\
Minimum & 4,074 & $-1,320$ & -24 \\
Maximum & 8,587 & 3,193 & 59 \\
\hline & & Parowan Valley & -10 \\
\hline Most recent (measured) & 36,642 & - & 27 \\
Minimum & 32,997 & $-3,645$ & -10 \\
Maximum & 46,693 & 10,051 & \\
\hline
\end{tabular}

1The difference between using the most recent PCCs and the minimum or maximum PCCs.

${ }^{2}$ The percent difference between the most recent PCC and the minimum or maximum PCC. 
Estimated annual groundwater withdrawals for each test basin were calculated using different PCC values. Method 1 uses the most recently measured PCC for each well to estimate groundwater withdrawal. Methods 2 and 3 use the historical minimum PCC and the historical maximum PCC, respectively, for each well to estimate groundwater withdrawal. Methods 4 and 5 use the historical mean PCC and historical median PCC for each well to estimate groundwater withdrawal. Method 6 uses the historical maximum PCC for complex wells and the most recently measured PCC for simple and borderline wells to estimate groundwater withdrawal. Method 7 uses the historical maximum PCC for complex and borderline wells and the most recently measured PCC for simple wells to estimate groundwater withdrawal. Method 8 uses the historical minimum PCC for complex wells and the most recently measured PCC for simple and borderline wells to estimate groundwater withdrawal. Method 9 uses the historical minimum PCC for complex and borderline wells and the most recently measured PCC for simple wells to estimate groundwater withdrawal. Method 10 uses the valley average of each well's most recently measured PCC to estimate groundwater withdrawal. Method 11 uses measured withdrawal from dedicated flowmeters (note, there are no wells in Tooele or Parowan Valleys with dedicated flowmeters; 24 wells in Goshen Valley have dedicated flowmeters; table 7). Historically, withdrawal in Tooele Valley has been calculated using the most recently measured PCC for each well (method 1, table 7); withdrawal in Parowan Valley has been calculated using the valley average PCC from all wells (method 10, table 7); withdrawal in Goshen Valley has been calculated using a combination of user-reported withdrawal from dedicated flowmeters and the most recently measured PCCs for those wells that do not have dedicated flowmeters (methods 11 and 1, respectively, table 7).

As noted, various methods were used to calculate annual groundwater withdrawal (table 7). Groundwater withdrawal estimated using the most recent PCC for each well (method 1, table 7) were compared to those calculated using other PCCs. Methods 6 through 10 (table 7) incorporate values calculated using method 1 and are therefore excluded from comparison in the following section because calculated annual groundwater withdrawal will be skewed toward those methods that include the most recently measured PCCs.

Table 7. Method definitions for calculating annual groundwater withdrawal and calculated groundwater withdrawal in Utah, 2016.

[PCC, power consumption coefficient; $\leq$, less than or equal to; - , no data]

\begin{tabular}{|c|c|c|c|c|}
\hline \multirow{2}{*}{$\begin{array}{l}\text { Method } \\
\text { number }\end{array}$} & \multirow{2}{*}{ PCC record(s) used to calculate annual groundwater withdrawal } & \multicolumn{3}{|c|}{$\begin{array}{l}\text { Estimated annual groundwater withdrawal } \\
\text { by basin, in acre-foot }\end{array}$} \\
\hline & & $\begin{array}{l}\text { Tooele Valley, } \\
\text { Utah }\end{array}$ & $\begin{array}{c}\text { Parowan } \\
\text { Valley, Utah }\end{array}$ & $\begin{array}{l}\text { Goshen } \\
\text { Valley, Utah1 }\end{array}$ \\
\hline Method 1 & Most recent (measured) & 5,394 & 36,642 & 22,646 \\
\hline Method 2 & Historical minimum & 4,074 & 32,997 & 22,433 \\
\hline Method 5 & Historical median & 5,758 & 39,937 & 22,576 \\
\hline Method 6 & $\begin{array}{l}\text { Historical maximum complex, most recent (measured) simple and borderline/wells } \\
\text { with } \leq \text { three historical records }\end{array}$ & 7,906 & 37,510 & - \\
\hline Method 7 & $\begin{array}{l}\text { Historical maximum complex and borderline/wells with } \leq \text { three historical records, } \\
\text { most recent (Measured) simple }\end{array}$ & 8,557 & 41,283 & - \\
\hline Method 10 & Valley average & 5,693 & 37,079 & 22,945 \\
\hline Method 11 & Flowmeter & - & - & - \\
\hline
\end{tabular}

1Withdrawal estimated using dedicated flowmeter withdrawal when available and with method indicated for wells without dedicated flowmeters. 


\section{Tooele Valley}

In Tooele Valley, the smallest percent difference from withdrawal calculated using the most recently measured PCC for each irrigation well, method 1 (excluding methods that partially use most recent values), is withdrawal calculated using the historical mean, method 4 , or historical median, method 5, PCCs for each irrigation well. Annual groundwater withdrawal calculated in 2016 using historical mean PCCs was 11-percent greater than withdrawal calculated with the most recently measured PCCs, and annual groundwater withdrawal calculated with historical median PCCs was 7-percent greater than withdrawal calculated using the most recently measured PCCs (table 8). In Tooele Valley, annual groundwater withdrawal calculated with historical mean or historical median PCCs are close to withdrawal calculated with the most recently measured PCCs and reduce the need to rate wells as frequently.

\section{Parowan Valley}

In Parowan Valley, the smallest percent difference from withdrawal calculated using the most recently measured PCC for each irrigation well, method 1 (excluding methods that partially use most recent values), is withdrawal calculated using the historical mean, method 4 , or historical median, method 5, PCCs from for each irrigation well in 2016. Annual groundwater withdrawal calculated in 2016 using historical mean and historical median was 9-percent greater than withdrawal calculated using the most recently measured PCCs (table 9). Because most of the wells in Parowan Valley are classified as simple, that is, their PCC does not vary much, using the valley average also is a good method for estimating annual groundwater withdrawal. However, this 1-percent difference between using the most recently measured PCCs and valley average PCCs to calculate withdrawal is skewed because the valley average is based on these records and may not represent actual withdrawal.

\section{Goshen Valley}

In Goshen Valley, withdrawal calculated using the most recently measured PCC for each irrigation well, method 1 , compared to withdrawal calculated with using the historical minimum, method 2, historical maximum, method 3 , historical mean, method 4 , historical median, method 5 , valley average, method 10, PCCs from for each irrigation wells in 2016 was similar. Annual groundwater withdrawal calculated in 2016 using each method is 2 percent or less than withdrawal calculated using the most recently measured PCCs (table 10). Because 80 percent of the wells in Goshen Valley have dedicated flowmeters, calculated groundwater withdrawal is similar regardless of the methods used to calculate withdrawal.

In 2016, Goshen Valley had 26 active irrigation wells that had power usage and historical PCCs. The smallest percent difference from withdrawal calculated using the most recently measured PCC for each irrigation well (excluding those partially calculated with the most recently measured values) is withdrawal calculated using historical mean, method 4 , or historical median, method 5, PCCs from each irrigation well in 2016. Annual groundwater withdrawal calculated in 2016 using historical mean and historical median was 14-percent greater than withdrawal calculated using the most recently measured PCCs (table 11). Although Goshen Valley has more complex than simple wells, annual groundwater withdrawal calculated using historical mean or historical median PCCs for active irrigation wells is close to withdrawal calculated using the most recently measured PCCs.

Table 8. Percent difference between estimated annual groundwater withdrawal calculated using various combinations of historical power consumption coefficients from irrigation wells in Tooele Valley, Utah, 2016.

[GW, groundwater; acre-ft, acre-foot]

\begin{tabular}{|c|c|c|c|c|c|c|c|c|c|c|c|}
\hline $\begin{array}{l}\text { Method } \\
\text { number }\end{array}$ & $\begin{array}{c}\text { Method } \\
1\end{array}$ & $\begin{array}{c}\text { Method } \\
2\end{array}$ & $\begin{array}{c}\text { Method } \\
3\end{array}$ & $\begin{array}{c}\text { Method } \\
4\end{array}$ & $\begin{array}{c}\text { Method } \\
5\end{array}$ & $\begin{array}{c}\text { Method } \\
\mathbf{6}\end{array}$ & $\begin{array}{c}\text { Method } \\
7\end{array}$ & $\begin{array}{c}\text { Method } \\
8\end{array}$ & $\begin{array}{c}\text { Method } \\
9\end{array}$ & $\begin{array}{c}\text { Method } \\
10\end{array}$ & $\begin{array}{c}\text { Annual GW } \\
\text { withdrawal } \\
\text { (acre-ft) }\end{array}$ \\
\hline Method 1 & 0 & 32 & -37 & -10 & -6 & -32 & -37 & 21 & 24 & -5 & 5,394 \\
\hline Method 2 & -24 & 0 & -53 & -32 & -29 & -48 & -52 & -8 & -6 & -28 & 4,074 \\
\hline Method 3 & 59 & 111 & 0 & 44 & 49 & 9 & 0 & 93 & 98 & 51 & 8,587 \\
\hline Method 4 & 11 & 46 & -31 & 0 & 4 & -25 & -30 & 34 & 37 & 5 & 5,962 \\
\hline Method 5 & 7 & 41 & -33 & -3 & 0 & -27 & -33 & 30 & 32 & 1 & 5,758 \\
\hline Method 6 & 47 & 94 & -8 & 33 & 37 & 0 & -8 & 78 & 82 & 39 & 7,906 \\
\hline Method 7 & 59 & 110 & 0 & 44 & 49 & 8 & 0 & 93 & 97 & 50 & 8,557 \\
\hline Method 8 & -18 & 9 & -48 & -25 & -23 & -44 & -48 & 0 & 2 & -22 & 4,444 \\
\hline Method 9 & -19 & 7 & -49 & -27 & -25 & -45 & -49 & -2 & 0 & -24 & 4,347 \\
\hline Method 10 & 6 & 40 & -34 & -5 & -1 & -28 & -33 & 28 & 31 & 0 & 5,693 \\
\hline
\end{tabular}


Table 9. Percent difference between estimated annual groundwater withdrawal calculated using various combinations of historical power consumption coefficients from irrigation wells in Parowan Valley, Utah, 2016.

[GW, groundwater; acre-ft, acre-foot]

\begin{tabular}{|c|c|c|c|c|c|c|c|c|c|c|c|}
\hline $\begin{array}{l}\text { Method } \\
\text { number }\end{array}$ & $\begin{array}{c}\text { Method } \\
1\end{array}$ & $\begin{array}{c}\text { Method } \\
2\end{array}$ & $\begin{array}{c}\text { Method } \\
\mathbf{3}\end{array}$ & $\begin{array}{c}\text { Method } \\
4\end{array}$ & $\begin{array}{l}\text { Method } \\
5\end{array}$ & $\begin{array}{c}\text { Method } \\
6\end{array}$ & $\begin{array}{c}\text { Method } \\
7\end{array}$ & $\begin{array}{c}\text { Method } \\
\mathbf{8}\end{array}$ & $\begin{array}{c}\text { Method } \\
9\end{array}$ & $\begin{array}{c}\text { Method } \\
10\end{array}$ & $\begin{array}{c}\text { Annual GW } \\
\text { withdrawal } \\
\text { (acre-ft) }\end{array}$ \\
\hline Method 1 & 0 & 11 & -22 & -8 & -8 & -2 & -11 & 2 & 6 & -1 & 36,642 \\
\hline Method 2 & -10 & 0 & -29 & -17 & -17 & -12 & -20 & -8 & -4 & -11 & 32,997 \\
\hline Method 3 & 27 & 42 & 0 & 17 & 17 & 24 & 13 & 30 & 35 & 26 & 46,693 \\
\hline Method 4 & 9 & 21 & -15 & 0 & 0 & 6 & -4 & 11 & 15 & 7 & 39,795 \\
\hline Method 5 & 9 & 21 & -14 & 0 & 0 & 6 & -3 & 11 & 16 & 8 & 39,937 \\
\hline Method 6 & 2 & 14 & -20 & -6 & -6 & 0 & -9 & 5 & 9 & 1 & 37,510 \\
\hline Method 7 & 13 & 25 & -12 & 4 & 3 & 10 & 0 & 15 & 20 & 11 & 41,283 \\
\hline Method 8 & -2 & 9 & -23 & -10 & -10 & -4 & -13 & 0 & 4 & -3 & 35,827 \\
\hline Method 9 & -6 & 5 & -26 & -13 & -14 & -8 & -16 & -4 & 0 & -7 & 34,530 \\
\hline Method 10 & 1 & 12 & -21 & -7 & -7 & -1 & -10 & 3 & 7 & 0 & 37,079 \\
\hline
\end{tabular}

Table 10. Percent difference between estimated annual groundwater withdrawal calculated using various combinations of historical power consumption coefficients from irrigation wells in Goshen Valley, Utah1', 2016.

[GW, groundwater; acre-ft, acre-foot; PCC, power consumption coefficient]

\begin{tabular}{lcccccccc}
\hline $\begin{array}{c}\text { Method } \\
\text { number }\end{array}$ & $\begin{array}{c}\text { Method } \\
\mathbf{1}\end{array}$ & $\begin{array}{c}\text { Method } \\
\mathbf{2}\end{array}$ & $\begin{array}{c}\text { Method } \\
\mathbf{3}\end{array}$ & $\begin{array}{c}\text { Method } \\
\mathbf{4}\end{array}$ & $\begin{array}{c}\text { Method } \\
\mathbf{5}\end{array}$ & $\begin{array}{c}\text { Method } \\
\mathbf{1 0}\end{array}$ & $\begin{array}{c}\text { Annual GW } \\
\text { withdrawal } \\
\text { (acre-ft) }\end{array}$ \\
\hline Method 1 & 0 & 1 & 0 & 0 & 0 & -1 & 22,646 \\
Method 2 & -1 & 0 & -1 & -1 & -1 & -2 & 22,433 \\
Method 3 & 0 & 1 & 0 & 1 & 0 & -1 & 22,688 \\
Method 4 & 0 & 1 & 0 & 0 & 0 & -2 & 22,575 \\
Method 5 & 0 & 1 & 0 & 0 & 0 & -2 & 22,576 \\
Method 10 & 1 & 2 & 1 & 2 & 2 & 0 & 22,945 \\
\hline
\end{tabular}

1For irrigation wells with dedicated flowmeters, user-reported withdrawal was used and for irrigation wells without dedicated flowmeters, PCCs were used to estimate withdrawal. 
Table 11. Percent difference between estimated annual groundwater withdrawal calculated using various combinations of historical power consumption coefficients (PCCs) from irrigation wells that have historical PCCs in Goshen Valley, Utah¹, 2016.

[GW, groundwater; acre-ft, acre-foot]

\begin{tabular}{|c|c|c|c|c|c|c|c|c|c|c|c|}
\hline $\begin{array}{l}\text { Method } \\
\text { number }\end{array}$ & $\begin{array}{c}\text { Method } \\
1\end{array}$ & $\begin{array}{c}\text { Method } \\
2\end{array}$ & $\begin{array}{c}\text { Method } \\
3\end{array}$ & $\begin{array}{c}\text { Method } \\
4\end{array}$ & $\begin{array}{c}\text { Method } \\
5\end{array}$ & $\begin{array}{c}\text { Method } \\
6\end{array}$ & $\begin{array}{c}\text { Method } \\
7\end{array}$ & $\begin{array}{c}\text { Method } \\
8\end{array}$ & $\begin{array}{c}\text { Method } \\
9\end{array}$ & $\begin{array}{c}\text { Method } \\
10\end{array}$ & $\begin{array}{c}\text { Annual GW } \\
\text { withdrawal } \\
\text { (acre-ft) }\end{array}$ \\
\hline Method 1 & 0 & 20 & -32 & -12 & -12 & -17 & -29 & 6 & 19 & -4 & 16,393 \\
\hline Method 2 & -17 & 0 & -43 & -27 & -27 & -30 & -41 & -11 & -1 & -20 & 13,663 \\
\hline Method 3 & 46 & 75 & 0 & 29 & 28 & 22 & 4 & 55 & 74 & 40 & 23,964 \\
\hline Method 4 & 14 & 36 & -22 & 0 & 0 & -5 & -19 & 21 & 35 & 9 & 18,617 \\
\hline Method 5 & 14 & 37 & -22 & 0 & 0 & -5 & -19 & 21 & 36 & 9 & 18,676 \\
\hline Method 6 & 20 & 44 & -18 & 5 & 5 & 0 & -15 & 27 & 43 & 15 & 19,640 \\
\hline Method 7 & 40 & 68 & -4 & 23 & 23 & 17 & 0 & 49 & 67 & 35 & 22,983 \\
\hline Method 8 & -6 & 13 & -36 & -17 & -17 & -21 & -33 & 0 & 12 & -10 & 15,430 \\
\hline Method 9 & -16 & 1 & -43 & -26 & -26 & -30 & -40 & -11 & 0 & -19 & 13,770 \\
\hline Method 10 & 4 & 25 & -29 & -8 & -9 & -13 & -26 & 11 & 24 & 0 & 17,069 \\
\hline
\end{tabular}

1This table includes active irrigation wells in Goshen Valley that have historical PCCs and 2016 power usage. Power consumption coefficient calculated withdrawal is used for all wells included in these annual groundwater estimates. It excludes four active irrigation wells that have flowmeters and did not have 2016 power usage reported.

\section{Calculated Versus Directly Measured Withdrawal in Goshen Valley}

Goshen Valley had 20 wells with dedicated flowmeters, 2016 power usage records, and historical PCCs. The smallest percent difference from withdrawal recorded by dedicated flowmeters, method 11, is withdrawal calculated using historical mean, method 4, or historical median, PCCs from each irrigation well in 2016. Annual groundwater withdrawal calculated in 2016 using historical mean and historical median was 5-percent greater than withdrawal reported by dedicated flowmeters (table 12). Annual groundwater withdrawal calculated in 2016 using the most recently measured, method 1, PCCs was 9-percent less than withdrawal reported by dedicated flowmeters, method 11 (table 12). Flowmeter reported withdrawal is more accurate than withdrawal calculated using PCCs (Marston, 2017). Annual groundwater withdrawal calculated using historical mean or historical median PCCs is closer to flowmeter withdrawal than withdrawal calculated using the most recently measured PCCs.

Because most of the wells in Goshen Valley are equipped with dedicated flowmeters, there is an opportunity to compare direct withdrawal measurements with each of the three categories of PCC-calculated withdrawal (complex, simple, and borderline) separately. For wells classified as complex, withdrawal calculated using method 1 (most recent), method 4 (historical mean), and method 10 (Valley Average) were closest to dedicated flowmeter measurements (12-percent less, 11-percent greater, and 11-percent less, respectively; table 13).
Calculated annual groundwater withdrawal for wells classified as simple yielded similar results. For simple wells, the smallest percent difference from withdrawal from dedicated flowmeters, method 11, is withdrawal calculated using the most recently measured, method 1 , and valley average, method 10, PCCs from irrigation wells in 2016. For simple wells, annual groundwater withdrawal calculated in 2016 using the most recently measured PCCs is 5-percent less than withdrawal from dedicated flowmeters; annual groundwater withdrawal calculated in 2016 using valley average PCCs is the same as dedicated flowmeter withdrawal (table 14). For simple wells, annual groundwater withdrawal calculated in 2016 using historical mean, method 4, or historical median PCCs, method 5, is 8 and 7 percent, respectively, greater than dedicated flowmeter withdrawal.

Annual groundwater withdrawal also was calculated for wells classified as borderline or with three or fewer historical PCC records. For these wells, the smallest percent difference from withdrawal from dedicated flowmeters, method 11, is withdrawal calculated using historical mean, method 4, historical median, method 5, PCCs for irrigation wells in 2016. Also, for these wells, annual groundwater withdrawal calculated in 2016 using historical mean PCCs was 1-percent greater than dedicated flowmeter withdrawal; annual groundwater withdrawal calculated using historical median PCCs was 2-percent less than dedicated flowmeter withdrawal (table 15). Withdrawal calculated using valley average was 7-percent less than dedicated flowmeter withdrawal, and withdrawal calculated using the most recently measured PCCs was 9-percent less than dedicated flowmeter withdrawal (table 15). 
Table 12. Percent difference between estimated annual groundwater withdrawal calculated using various combinations of historical power consumption coefficients (PCCs) from irrigation wells that have historical PCCs, 2016 power usage, and dedicated flowmeters in Goshen Valley, Utah11, 2016.

[GW, groundwater; acre-ft, acre-foot]

\begin{tabular}{|c|c|c|c|c|c|c|c|c|c|c|c|c|}
\hline $\begin{array}{l}\text { Method } \\
\text { number }\end{array}$ & $\begin{array}{c}\text { Method } \\
1\end{array}$ & $\begin{array}{c}\text { Method } \\
2\end{array}$ & $\begin{array}{c}\text { Method } \\
3\end{array}$ & $\begin{array}{c}\text { Method } \\
4\end{array}$ & $\begin{array}{c}\text { Method } \\
5\end{array}$ & $\begin{array}{c}\text { Method } \\
6\end{array}$ & $\begin{array}{c}\text { Method } \\
7\end{array}$ & $\begin{array}{c}\text { Method } \\
8\end{array}$ & $\begin{array}{c}\text { Method } \\
9\end{array}$ & $\begin{array}{c}\text { Method } \\
10\end{array}$ & $\begin{array}{c}\text { Method } \\
11\end{array}$ & $\begin{array}{c}\text { Annual GW } \\
\text { withdrawal } \\
\text { (acre-ft) }\end{array}$ \\
\hline Method 1 & 0 & 20 & -34 & -13 & -14 & -18 & -31 & 7 & 19 & -2 & -9 & 14,888 \\
\hline Method 2 & -17 & 0 & -45 & -28 & -28 & -32 & -42 & -11 & -1 & -19 & -24 & 12,370 \\
\hline Method 3 & 51 & 81 & 0 & 30 & 30 & 24 & 5 & 61 & 80 & 47 & 37 & 22,416 \\
\hline Method 4 & 15 & 39 & -23 & 0 & 0 & -5 & -20 & 23 & 38 & 13 & 5 & 17,182 \\
\hline Method 5 & 16 & 39 & -23 & 0 & 0 & -5 & -20 & 24 & 38 & 13 & 5 & 17,241 \\
\hline Method 6 & 22 & 47 & -19 & 6 & 5 & 0 & -15 & 30 & 45 & 19 & 11 & 18,135 \\
\hline Method 7 & 44 & 73 & -4 & 25 & 24 & 18 & 0 & 54 & 72 & 40 & 31 & 21,435 \\
\hline Method 8 & -6 & 13 & -38 & -19 & -19 & -23 & -35 & 0 & 12 & -9 & -15 & 13,925 \\
\hline Method 9 & -16 & 1 & -44 & -27 & -28 & -31 & -42 & -10 & 0 & -18 & -24 & 12,477 \\
\hline Method 10 & 3 & 23 & -32 & -11 & -11 & -16 & -29 & 10 & 22 & 0 & -7 & 15,265 \\
\hline Method 11 & 10 & 32 & -27 & -5 & -5 & -10 & -24 & 18 & 31 & 7 & 0 & 16,379 \\
\hline
\end{tabular}

1This table includes active irrigation wells in Goshen Valley that have historical PCCs, 2016 power usage, and dedicated flowmeters. It excludes 10 active irrigation wells that do not have dedicated flowmeters and 2016 power usage reported.

Table 13. Percent difference between estimated annual groundwater withdrawal calculated using various combinations of historical power consumption coefficients (PCCs) from complex irrigation wells that have historical PCCs, 2016 power usage, and dedicated flowmeters in Goshen Valley, Utah', 2016.

[GW, groundwater; acre-ft, acre-foot]

\begin{tabular}{|c|c|c|c|c|c|c|c|c|}
\hline $\begin{array}{l}\text { Method } \\
\text { number }\end{array}$ & $\begin{array}{c}\text { Method } \\
1\end{array}$ & $\begin{array}{l}\text { Method } \\
2\end{array}$ & $\begin{array}{c}\text { Method } \\
3\end{array}$ & $\begin{array}{l}\text { Method } \\
4\end{array}$ & $\begin{array}{l}\text { Method } \\
5\end{array}$ & $\begin{array}{c}\text { Method } \\
10\end{array}$ & $\begin{array}{c}\text { Method } \\
11\end{array}$ & $\begin{array}{c}\text { Annual GW } \\
\text { withdrawal } \\
\text { (acre-ft) }\end{array}$ \\
\hline Method 1 & 0 & 32 & -45 & -21 & -25 & -2 & -12 & 3,980 \\
\hline Method 2 & -24 & 0 & -58 & -40 & -43 & -26 & -34 & 3,018 \\
\hline Method 3 & 82 & 140 & 0 & 43 & 36 & 78 & 59 & 7,228 \\
\hline Method 4 & 27 & 67 & -30 & 0 & -5 & 24 & 11 & 5,039 \\
\hline Method 5 & 34 & 76 & -26 & 6 & 0 & 31 & 17 & 5,320 \\
\hline Method 10 & 2 & 34 & -44 & -20 & -24 & 0 & -11 & 4,053 \\
\hline Method 11 & 14 & 50 & -37 & -10 & -15 & 12 & 0 & 4,539 \\
\hline
\end{tabular}

1 This table includes active irrigation wells classified as complex in Goshen Valley that have historical PCCs, 2016 power usage, and flowmeters. It excludes 10 active irrigation wells that do not have flowmeters and 2016 power usage reported. 
Table 14. Percent difference between estimated annual groundwater withdrawal calculated using various combinations of historical power consumption coefficients (PCCs) from simple irrigation wells that have historical PCCs, 2016 power usage, and dedicated flowmeters in Goshen Valley, Utah1, 2016.

[GW, groundwater; acre-ft, acre-foot]

\begin{tabular}{lcrrrrrrr}
\hline $\begin{array}{l}\text { Method } \\
\text { number }\end{array}$ & $\begin{array}{c}\text { Method } \\
\mathbf{1}\end{array}$ & $\begin{array}{c}\text { Method } \\
\mathbf{2}\end{array}$ & $\begin{array}{c}\text { Method } \\
\mathbf{3}\end{array}$ & $\begin{array}{c}\text { Method } \\
\mathbf{4}\end{array}$ & $\begin{array}{c}\text { Method } \\
\mathbf{5}\end{array}$ & $\begin{array}{c}\text { Method } \\
\mathbf{1 0}\end{array}$ & $\begin{array}{c}\text { Method } \\
\mathbf{1 1}\end{array}$ & $\begin{array}{c}\text { Annual GW } \\
\text { withdrawal } \\
\text { (acre-ft) }\end{array}$ \\
\hline Method 1 & 0 & 4 & -25 & -12 & -11 & -5 & -5 & 2,925 \\
Method 2 & -4 & 0 & -28 & -16 & -15 & -8 & -8 & 2,818 \\
Method 3 & 34 & 39 & 0 & 17 & 18 & 27 & 27 & 3,906 \\
Method 4 & 14 & 18 & -15 & 0 & 1 & 8 & 8 & 3,339 \\
Method 5 & 13 & 17 & -15 & -1 & 0 & 7 & 7 & 3,301 \\
Method 10 & 5 & 9 & -21 & -8 & -7 & 0 & 0 & 3,079 \\
Method 11 & 5 & 9 & -21 & -8 & -7 & 0 & 0 & 3,079 \\
\hline
\end{tabular}

${ }^{1}$ This table includes active irrigation wells classified as simple in Goshen Valley that have historical PCCs, 2016 power usage, and flowmeters. It excludes 10 active irrigation wells that do not have flowmeters and 2016 power usage reported.

Table 15. Percent difference between estimated annual groundwater withdrawal calculated using various combinations of historical power consumption coefficients (PCCs) from borderline irrigation wells and wells with three or fewer historical PCCs that have historical PCCs, 2016 power usage, and dedicated flowmeters in Goshen Valley, Utah1, 2016.

[GW, groundwater; acre-ft, acre-foot]

\begin{tabular}{lrrrrrrrr}
\hline $\begin{array}{l}\text { Method } \\
\text { number }\end{array}$ & $\begin{array}{c}\text { Method } \\
\mathbf{1}\end{array}$ & $\begin{array}{c}\text { Method } \\
\mathbf{2}\end{array}$ & $\begin{array}{c}\text { Method } \\
\mathbf{3}\end{array}$ & $\begin{array}{c}\text { Method } \\
\mathbf{4}\end{array}$ & $\begin{array}{c}\text { Method } \\
\mathbf{5}\end{array}$ & $\begin{array}{c}\text { Method } \\
\mathbf{1 0}\end{array}$ & $\begin{array}{c}\text { Method } \\
\mathbf{1 1}\end{array}$ & $\begin{array}{c}\text { Annual GW } \\
\text { withdrawal } \\
\text { (acre-ft) }\end{array}$ \\
\hline Method 1 & 0 & 22 & -29 & -9 & -7 & -2 & -9 & 7,982 \\
Method 2 & -18 & 0 & -42 & -26 & -24 & -20 & -25 & 6,534 \\
Method 3 & 41 & 73 & 0 & 28 & 31 & 39 & 29 & 11,282 \\
Method 4 & 10 & 35 & -22 & 0 & 2 & 8 & 1 & 8,805 \\
Method 5 & 8 & 32 & -24 & -2 & 0 & 6 & -2 & 8,621 \\
Method 10 & 2 & 24 & -28 & -8 & -6 & 0 & -7 & 8,133 \\
Method 11 & 10 & 34 & -22 & 0 & 2 & 8 & 0 & 8,761 \\
\hline
\end{tabular}

1This table includes active irrigation wells classified as borderline or with three or fewer historical PCCs in Goshen Valley that have historical PCCs, 2016 power usage, and flowmeters. It excludes 10 active irrigation wells that do not have flowmeters and 2016 power usage reported. 
For wells classified as simple and borderline, historical mean and historical median methods were less than 8-percent different from dedicated flowmeter withdrawal. For wells classified as complex, historical mean and historical median methods were less than 17 percent, and most recent and valley average PCCs were 12 percent or less different from dedicated flowmeter withdrawal. Withdrawal estimates from individual wells could be improved with more frequent PCC measurements, with complex wells receiving the most benefit. Although there are uncertainties in estimates of withdrawal from individual wells, basin-wide withdrawal estimates incorporating all the wells (simple and complex) in a basin likely average some of the variability yielding more accurate estimates for the basin as a whole as compared to individual wells, especially with respect to complex wells.
Goshen Valley provides an opportunity to compare direct flow measurements with PCC estimated flow because Goshen Valley has 20 wells with dedicated flowmeters, 2016 power consumption data, and historical PCCs. The season-long PCC for each well can be calculated using the withdrawal from the dedicated flowmeter and the yearly power consumption. The season-long PCC calculated from dedicated flowmeters and the instantaneous measured PCC from the most recently measured PCCs was compared to assess what, if any, differences arise from using an instantaneous PCC compared to a season-long PCC (fig. 7). Season-long PCC compared to instantaneous PCC shows that there is no consistent bias using instantaneous PCCs.

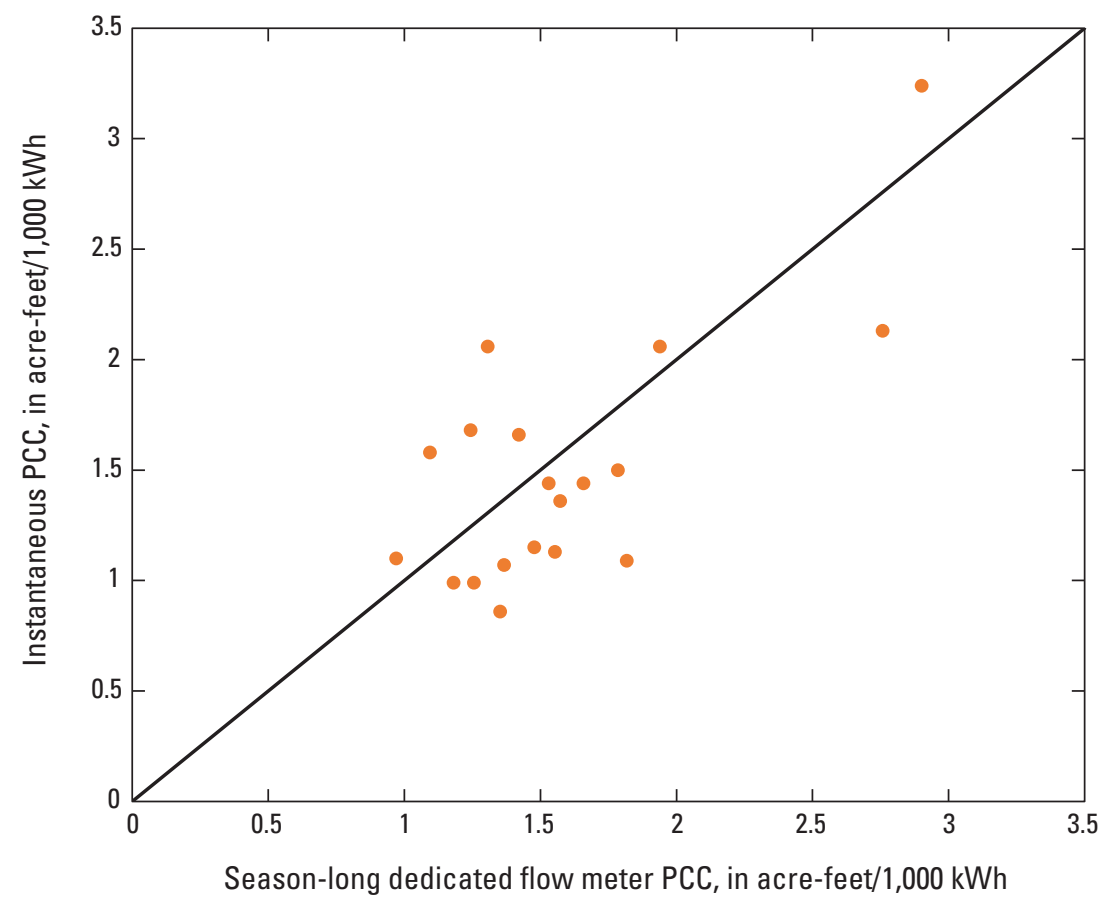

Figure 7. Comparison of season-long power consumption coefficient (PCC) calculated from dedicated flowmeters and the instantaneous measured PCC from the most recently measured PCCs in Goshen Valley, Utah, using 20 wells with dedicated flowmeters, 2016 power consumption, and historical PCCs. [kWh, kilowatt per hour.] 


\section{Summary}

Historical power consumption coefficient (PCC) records can be used to classify wells as simple, complex, or borderline based on the coefficient of variation (CV). The percent difference between methods for calculating annual groundwater withdrawal in the Tooele, Parowan, and Goshen Valleys was calculated to assess what, if any, difference the combination of PCC values used to estimate groundwater withdrawal has on the basin's estimated groundwater withdrawal. For all three test basins in 2016, using the historical mean PCC to calculate annual groundwater withdrawal is close to using the most recently measured PCC to calculated annual groundwater withdrawal. In Tooele, Parowan, and Goshen Valleys, withdrawal calculated using maximum and minimum historical PCCs differs by as much as 59 percent when compared to withdrawal calculated using the most recently measured PCCs (table 6). In Goshen Valley, withdrawal calculated using historical mean or historical median PCCs is closer to flowmeter reported withdrawal than withdrawal calculated using the most recently measured PCCs.

In Goshen Valley, using a subset of wells with both dedicated flowmeters and 2016 power usage, annual groundwater withdrawal calculated using historical mean PCCs was 5-percent greater than annual groundwater withdrawal measured using dedicated flowmeters (fig. 8). Annual groundwater withdrawal calculated using the most recently measured PCCs was 9-percent less than withdrawal from dedicated flowmeters. Assuming dedicated flowmeters represent the most accurate method available to estimate groundwater withdrawal, in the case of Goshen Valley, using historical mean PCCs to calculate withdrawal appears to be the most accurate of the methods evaluated (table 7; fig. 8). The historical mean could average out changes in system configuration and timing of the measurement rather than using a single most recently measured PCC. Regardless of the composition of well configuration in a basin, the implementation of dedicated flowmeters reduces uncertainty in basin-wide groundwater withdrawal estimates. Consequently, the historical mean PCC was compared to selected methods of estimating withdrawal in each of the three basins.

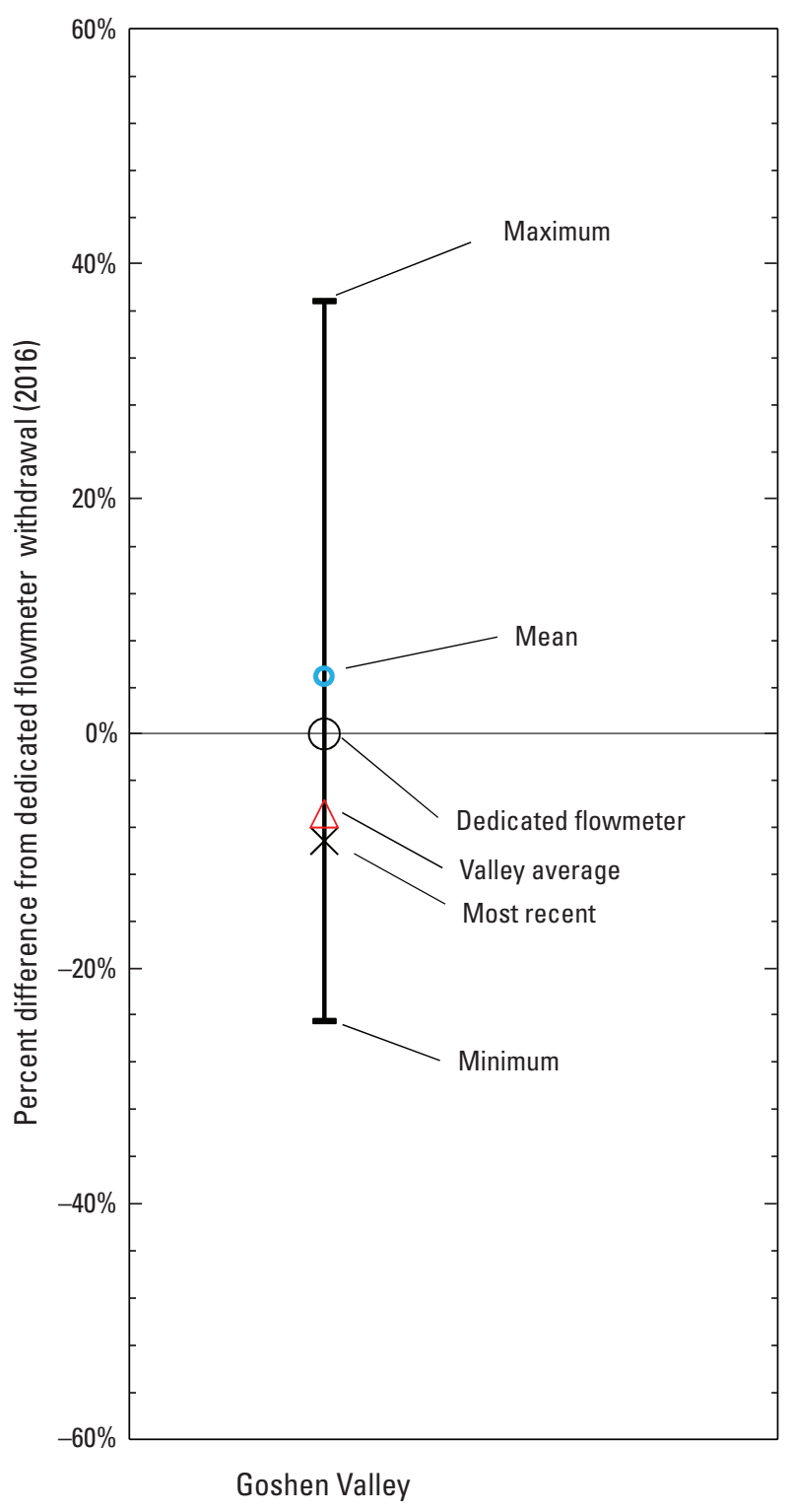

Figure 8. Percent difference between dedicated flowmeter withdrawal and withdrawal calculated using other methods in Goshen Valley, Utah, 2016. 
The difference between annual groundwater withdrawal calculated using historical minimum PCCs, historical maximum PCCs, historical mean PCCs, valley average PCCs, and the most recently measured PCCs for all basins in 2016 is shown in figure $9 \mathrm{~A}$. The difference between withdrawal calculated using these methods is larger for Parowan than Tooele and Goshen Valleys; however, approximately nine times more water is withdrawn in Parowan Valley than in Tooele Valley and two times more water is withdrawn in Parowan Valley than in Goshen Valley (fig. 9A). Normalizing these withdrawals allows for a direct comparison between differences in withdrawal calculated using different combinations of PCCs in each basin.

The normalized percent difference from withdrawal calculated with these methods and withdrawal calculated using historical mean PCCs is shown in figure 9B. Tooele Valley has the most complex wells (fig. 10A) and the largest normalized range of withdrawal when compared to withdrawal calculated using historical mean PCCs; 44-percent greater using historical maximum; and 32-percent less using historical minimum (fig. 9B; table 8). Parowan Valley has the most simple wells (fig. 10B) and the smallest normalized range of withdrawal; 17-percent greater using historical maximum and 17-percent less using historical minimum (fig. 9B; table 9). Goshen Valley has more complex wells than Parowan Valley and fewer complex wells than Tooele Valley, and Goshen Valleys normalized range of withdrawals when compared to withdrawal calculated using historical mean PCCs is between these two basins; 29-percent greater using historical maximum and 27 percent using historical minimum (figs. $9 B$, $10 C$; table 11). Based on the analysis of the three test basins, basins with a greater proportion of complex wells without dedicated flowmeters have greater uncertainty of estimated groundwater withdrawal than basins with a greater proportion of simple wells.
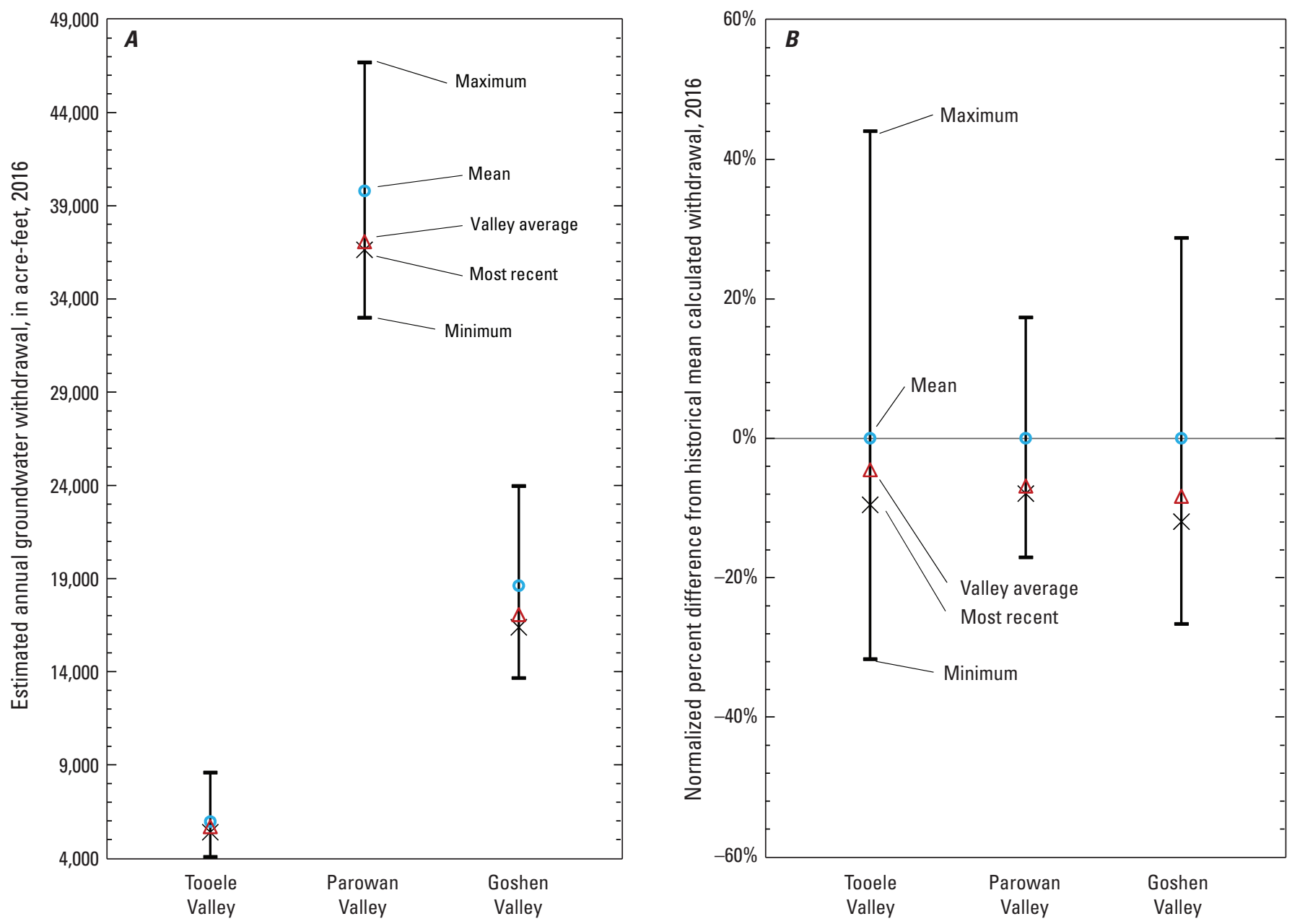

Figure 9. Estimated annual groundwater withdrawal calculated using historical minimum power consumption coefficients (PCCS). $A$, Historical maximum PCCs, historical mean PCCs, valley average PCCs, and the most recently measured PCCs; and $B$, Normalized percent difference between annual groundwater withdrawal calculated using historical mean PCCs and annual groundwater withdrawal calculated using other methods (historical minimum PCCs, historical maximum PCCs, valley average PCCs, and most recently measured PCCs) in 2016 for Tooele, Parowan, and Goshen Valleys, Utah. [\%, percent.] 
$\boldsymbol{A}$

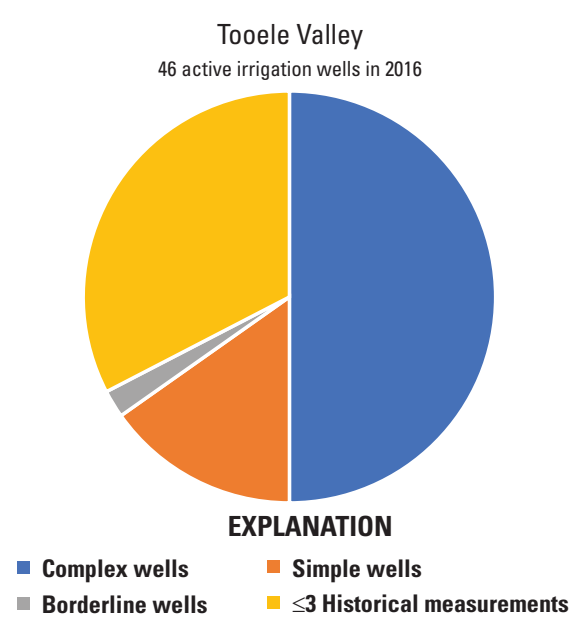

B

Parowan Valley

115 active irrigation wells in 2016

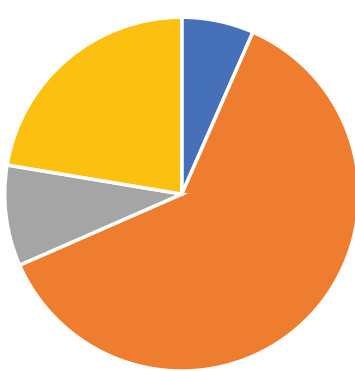

EXPLANATION

- Complex wells $\quad$ Simple wells

- Borderline wells $\quad \leq \mathbf{3}$ Historical measurements
Groundwater withdrawal estimates could be improved by incorporating methods and techniques outlined in this report. The CV could be calculated for each well in each basin across the state of Utah, where PCC records exist. The percentage of complex wells could then be determined based on the thresholds outlined in this paper. In basins with a high percentage of complex wells, field visits to verify correct classification could be done and repeat measurements of PCCs could be completed more frequently than in basins with more simple wells. The installation of dedicated flowmeters would improve estimates of basin-wide withdrawal, with installation on complex wells likely providing the most benefit. Similarly, if a well's configuration is changed from simple to complex, then installation of a dedicated flowmeter would assist in withdrawal estimates.

Sources of variability of PCCs can be attributed to a variety of user and environmental factors, such as errors when measuring PCC caused by low pressure or the timing of the measurement. For instance, in a complex well system, one segment of the pipe could be in use during one visit, and the following visit, multiple pipes could be in use. These sources of variability contribute to the difficulty arising from using a single PCC to calculate withdrawal and support the use of mean or median PCCs, which lessen the effects of the large ranges in variability over time when annual groundwater withdrawal is calculated for an entire basin.
C

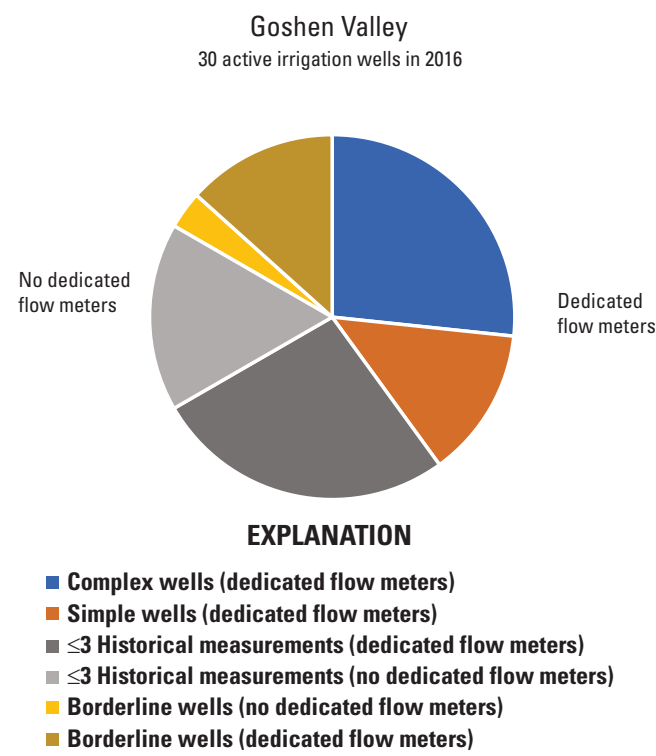

Figure 10. Wells classified as simple, complex, and borderline (three or fewer historical power consumption coefficients) in each basin, $A$, Tooele; $B$, Parowan; and $C$, Goshen, Utah, 2016. 


\section{References Cited}

Dash, R.G., Troutman, B.M., and Edelmann, P., 1999, Comparison of two approaches for determining ground-water discharge and pumpage in the lower Arkansas River Basin, Colorado, 1997-98: U.S. Geological Survey Water-Resources Investigations Report 99-4221, 39 p., https://doi.org/10.3133/wri994221.

Gold, B.L., 2020, Historical power consumption coefficients and 2016 power usage for irrigation wells in Tooele, Parowan, and Goshen Valley, Utah: U.S. Geological Survey data release, https://doi.org/10.5066/P92UVVV6.
Hurr, R.T., and Litke, D.W., 1989, Estimating pumping time and groundwater withdrawals using energy-consumption data: U.S. Geological Survey Water-Resources Investigations Report 89-4107, 27 p., https://doi.org/10.3133/wri894107.

Marston, T.M., 2017, Water resources of Parowan Valley, Iron County, Utah: U.S. Geological Survey Scientific Investigation Report 2017-5033, 45 p., https://doi.org/10.3133/sir20175033.

Reed, G.F., Lynn, F., and Meade, B.D., 2002, Use of coefficient of variation in assessing variability of quantitative assays: Clinical and Diagnostic Laboratory Immunology, v. 9, no. 6, p. 1235-1239, https://doi.org/10.1128\%2FCDLI.10.6.1162.2003.

Zwillinger, D., and Kokoska, S., 2000, CRC Standard probability and statistics tables and formulae: Boca Raton, FL, Imprint CRC Press, 200 p. 

For more information concerning the research in this report, contact the Director, Utah Water Science Center

U.S. Geological Survey

2329 West Orton Circle

Salt Lake City, Utah 84119-2047

801-908-5000

https://ut.water.usgs.gov

Publishing support provided by the U.S. Geological Survey Science Publishing Network, Sacramento Publishing Service Center 
总

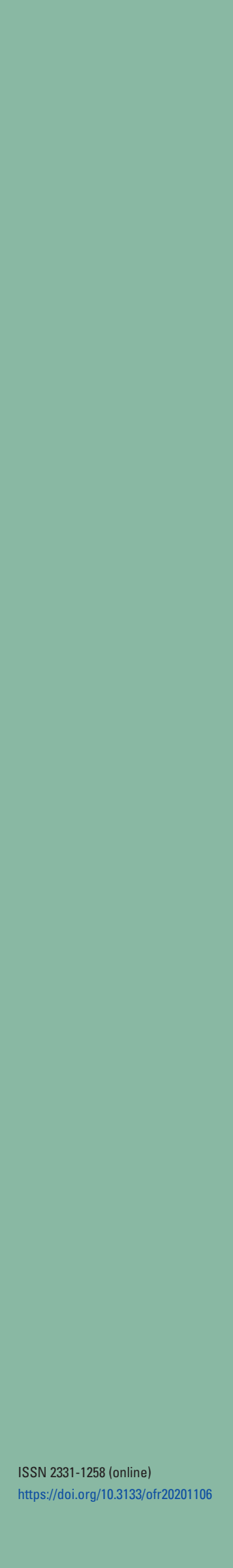

